\title{
Reference Waste Package Environment Report
}

\author{
W. E. Glassley
}

Manuscript date: October 1, 1986

\section{DISClaIMER}

This report was prepered as an acconat of wort spononed by as wency of the United Sutes

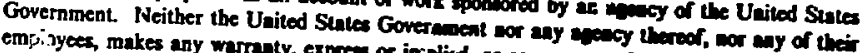

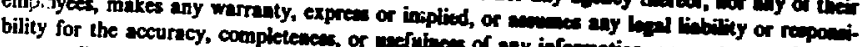
process disclosed, or reprements that in werubes of asy informetion, epparatus product, ur

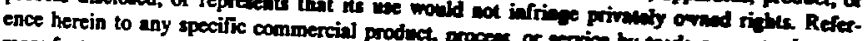

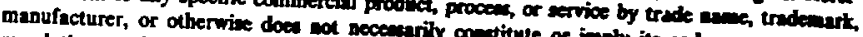
mendation, or favoring by the Uaited Stntes Coneritute or inply its ealoneneat, recon.

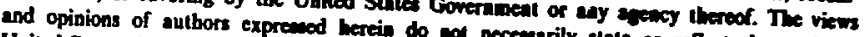
United States Government or any seacy thereor.

\section{LAWRENCE LIVERMORE NATIONAL LABORATORY University of California - Livermore, California - 94550}

Available from: National Technical Information Service - U.S. Department of Commerce 5285 Port Royal Road • Springfield, VA 22161 - A02 - (Microfiche A01) 


\section{Contents}

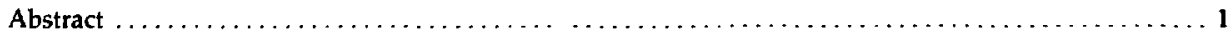

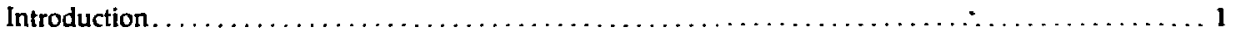

Geochemistry and Petrology of the Near-Field Environment $\ldots \ldots \ldots \ldots \ldots \ldots \ldots \ldots \ldots \ldots \ldots \ldots$

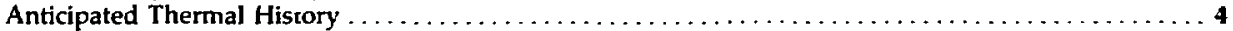

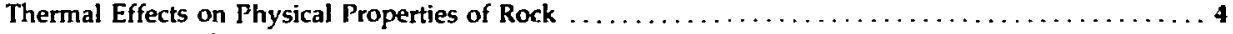

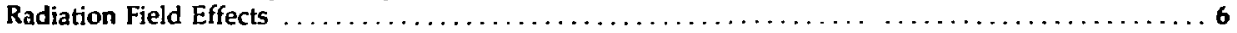

Thermal Effects on Water Flow in the Vicinity of Waste Packages $\ldots \ldots \ldots \ldots \ldots \ldots \ldots \ldots \ldots \ldots 7$

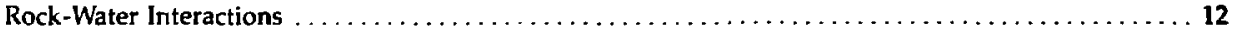

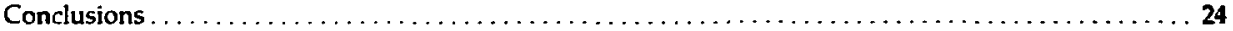

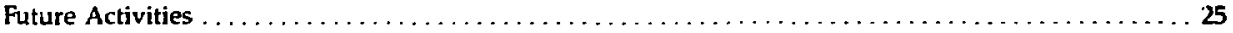

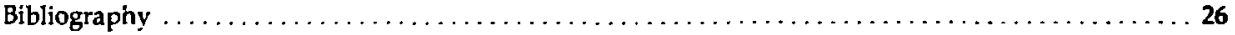




\section{Reference Waste Package Environment Report}

\section{Abstract}

One of three candidate repository sites for high-level radioactive waste packages is located at Yucca Mountain, Nevada, in rhyolitic tuff 700 to $1400 \mathrm{ft}$ above the static water table. Calculations indicate that the package environment will experience a maximum temperature of $\sim 230^{\circ} \mathrm{C}$ at 9 years after emplacement. For the next 300 years the rock within $1 \mathrm{~m}$ of the waste packages will remain dehydrated. Preliminary results suggest that the waste package radiation field will have very little effect on the mechanical properties of the rock. Radiolysis products will have a negligible effect on the rock even after rehydration. Unfractured specimens of repository rock show no change in hydrologic characteristics during repeated dehydration-rehydration cycles. Fractured samples with initially high permeabilities show a striking permeability decrease during dehydration-rehydration cycling, which may be due to fracture healing via deposition of silica. Rock-water interaction studies demonstrate low and benign levels of anions and most cations. The development of sorptive secordary phases such as zeolites and clays suggests that anticipated rock-water interaction may produce beneficial changes in the package environment.

\section{Introduction}

Lawrence Livermore National Laboratory (LLNL) is developing designs for high level nuclear waste packages as part of the Nevada Nu-lear Waste Storage Investigation (NNWSI) Project. Performance objectives for the waste packages, as given in the Nuclear Regulatory Commission's regulations (10 CFR 60), require prediction of the corrosion performance of the package metal container for up to 1000 years and the performance of waste forms for up to 10,000 year:.

Successful prediction of performance for long time periods requires a thorough understanding of the chemical and physical environments within which the waste packages will be placed. Definition of the waste package environment involves detailed description of the pre-emplacement (ambient) conditions at the proposed repository horizon and determination of the changes that will take place after the waste packages are emplaced. The effects that can be expected from development of the repository and emplacement of the waste packages are physical changes in the rock unit due to mining activities, changes in the physical and chemical properties of the rock and vadose water due to the waste-related radiation field, and modification of the ambient rock/water system and hydrodynamic regime due to the thermal load generated by the waste packages. This report deals with experimental work that addresses the effects related to the radiation field and the thermal load attributable to waste package emplacement.

The radiation field from the waste forms will consist of alpha, beta, neutron, and gamma radiation. Alpha and beta radiation will be contained within the waste package because of the short penetration of these farticles. Neutrons and gamma radiation will penetrate the waste package and interact with the environment. Neutrons can cause damage to material by displacing atoms as a result of atomic collisions. The damage from atomic displacements in the host rock minerals would be very small at the flux levels present in the waste forms and would not significantly affect the properties of the mat:rial (Van Konynenburg, 1984; Grasse et al., 1982). The neutrons would not have a significant effect on the water chemistry, again because the flux would be small. Gamma radiation interarts with matter by ionization mechanisms. The effects of gamma interaction with tuff will largely be transient and are not expected to cause significant change in tinc rock or mineral properties (Durham et al., 1985). Gamma 
radiation can cause changes in water chemistry due to the production of radiolytic species. The research conducted in this area is described below under the heading "Radiation Field Effects."

The thermal load imposed by the waste packages on the near field environment will be a function of the waste form. Wastes that may be emplaced in the repository include spent fuel from commercial power reactors as well as borosilicate glass from spent commercial high-level waste and reprocessed defense high-level waste. The actual thermal output for the spent fuel will depend on burn-up history, the time out of reactor, and whether consolidated fuel rods or intact fuel assemblies are stored in the container. Thermal output of the processed waste will depend on the composition of the glass. The resulting rise in temperature would alter the local hydrologic system and would cause the pore water contained in rock in the vicinity of waste packages to vaporize. Fol- lowing dehydration, rehydration of the near field environment will occur as the waste package temperature drops. Performance of the centainment barrier and the waste forms is closely tied to the amount of water in the system and to the flow mechanisms operating in the vicinity of the waste packages. The rates and mechanisms of dehydration and rehydration of Topopah Spring tuff are being investigated in laboratory experiments using intact and fractured rock samples. This work is discussed below under the heading "Thermal Effects on Water Flow in the Vicinity of Waste Packages."

The elevated temperature in the host rock would also affect the chemistry of any water in the system. To assess the potential for changes in water chemistry, a series of tests have been conducted at temperatures from 90 to $250^{\circ} \mathrm{C}$ using a variety of Topopah Spring tuff samples and a representative groundwater. This work is described below under the heading "Rock-Water Interactions."

\section{Geochemistry and Petrology of the Near-Field Environment}

The potential repository site is located at Yucca Mountain in Nye County, Nevada. The potential repository horizon is in the lower densely welded and devitrified portion of the Topopah Spring Member of the Paintbrush Tuff. The Topopah Spring Member is a complex cooling unit within which degree of welding and devitrification varies (Bish et al., 1982). Bulk rock analyses demonstrate that this cooling unit is composed of quartz latite, which is restricted to the upper $50 \mathrm{~m}$ of the member, and rhyolite (Schuraytz, 1985). The rhyolite exhibits a small range in composition with low standard deviations for ail major oxides (Table 1). The potential repository horizon is located within the rhyolitic portion of the unit. The small variation in geochemistry demonstrates that the composition of the waste package host rock may be considered uniform.

The magmatic mineralogy of the waste package environment host rock is sodic plagioclase, sanidine, and minor quartz, biotite, amphibole, iron-titanium oxides, allanite, and zircon. These phases occur as phenocrysts and make up less than $2 \%$ of the rock volume (Lipman et al., 1966; Bish et al., 1981, 1982; Vaniman et al., 1984; Warren et al. 1984). The remainder of the rock volume consists of products resulting from devitrification,

Table 1. Percentages of major constituents in Topopah Springs tuff, drill core USW GU-3, samples 60, 61, and 62. $\mathrm{Fe}_{2} \mathrm{O}_{3}$ represents total iron. (From Schuraytz, 1985.)

\begin{tabular}{cccccc}
\hline Constituent & \multicolumn{1}{c}{60} & 61 & 62 & Average & Std Dev \\
\hline $\mathrm{SiO}_{2}$ & 78.4 & 78.9 & 78.9 & 78.73 & 0.24 \\
$\mathrm{Al}_{2} \mathrm{O}_{3}$ & 12.0 & 12.3 & 12.2 & 12.17 & 0.12 \\
$\mathrm{Fe}_{2} \mathrm{O}_{3}$ & 1.016 & 0.973 & 1.000 & 0.996 & 0.018 \\
$\mathrm{C2O}$ & 0.492 & 0.451 & 0.480 & 0.474 & 0.017 \\
$\mathrm{MgO}$ & 0.1271 & 0.1281 & 0.1126 & 0.123 & 0.007 \\
$\mathrm{TiO}_{2}$ & 0.1108 & 0.0927 & 0.0984 & 0.101 & 0.008 \\
$\mathrm{Na}_{2} \mathrm{O}$ & 4.07 & 3.92 & 4.25 & 4.08 & 0.13 \\
$\mathrm{~K}_{2} \mathrm{O}$ & 3.71 & 3.18 & 2.94 & 3.28 & 0.32 \\
$\mathrm{P}_{2} \mathrm{O}_{5}$ & 0.01 & 0.01 & 0.03 & 0.02 & 0.01 \\
$\mathrm{MnO}$ & 0.0624 & 0.0455 & 0.0488 & 0.052 & 0.007 \\
\hline
\end{tabular}


vapor phase crystallization, and alteration. These secondary minerals include cristobalite, alkali feldspars, and smectite clays (Vaniman et al., 1984). Within the potential repository horizon, mineralogical variation is limited to minor differences in the relative proportions of these phases.

The mineralogy of fracture coatings within the waste package environment host rock consists of cryptocrystalline mordenite with varying proportions of quartz, feldspar, cristobalite, heulandite/ clinoptilolite, calcite and smectite (Carlos, 1985). Textural relationships demonstrate that few of these minerals grew contemporaneously. Morphological features suggest that crystallization took place during different time intervals, with characteristic minerals or mineral assemblages representing each time interval (Carlos, 1985).

The geometric relationship between authigenic zeolitic zones and lithologic boundaries in rork units immediately below the repository horizon suggests that the zeolitic zones were established before and/or concurrently with block faulting. which affected the region about 11 million years ago (Levy, 1984; Orize et al., 1985). By analogy, formation of authigenic minerals in the repository horizon probably occurred during the same period.

The authigenic mineralogy reflects interaction of the rock with an aqueous fluid phase shortly after deposition of the rock unit (Levy, 1984). Since that time the rock within the repository horizon has been within the unsaturated zone, as suggested by fracture mineralogy and host rock alteration at drill core site USW G-4 (Carlos, 1985). The static water level is currently 700 to 1400 st below the repository horizon (Ortiz et al.. 1985).

The composition of pore fluid in the repository site will be established when the Exploratory Shaft Test Program recovers rock from the repository horizon. Circumstantial evidence suggests that tests conducted prior to completion of the exploratory shaft can closely approximate repository pore fluid chemistry by use of water recovered from well J-13, which is located to the east of Yucca Mountain. The elevation at J-13 is lower than at Yucca Mountain, and the Topopah Spring tuff lies below the water table there, forming the major producing horizon for the well. The chemistry of J-13 water is similar to that found in holes drilled to sample water from below the water table at Yucca Mountain (Ogard and Kerrisk, 1984). Water from well J-13 is also similar to unsaturated zone water obtained from tuffs at Rainier Mesa, which is north of Yucca Mountain (Table 2; White et al., 1980; Henne, 1982). Thus the water chemistry for J-13 is expected to be close to that of the vadose water in the Topopah Spring tuff in the unsaturated zone. Until samples of water from the unsaturated zone are available, the water from well J-13 has been ador.ted as a reference groundwater for NNWSI experimental work.

Table 2. Average composition of interstitial, fracture, and tonsel water from unsaturated zone of Rainier Mesa compared with well J-13 water. (All values except pH are in mmols/L.)

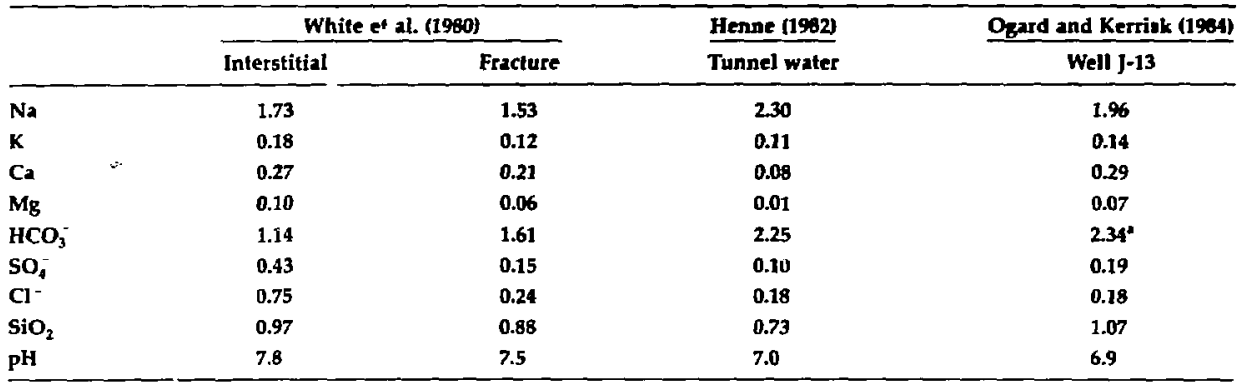

\footnotetext{
Measured alkalinity.
} 


\section{Anticipated Thermal History}

Waste package conceptual designs suggest that spent fuel waste packages may generate a thermal output of between 1.3 and $3.3 \mathrm{~kW}$ per container, while processed high level waste in the form of borosilicate glass may have an output of between 0.25 and $0.47 \mathrm{~kW}$ per container ( $\mathrm{O}^{\prime} \mathrm{Neal}$ et al., 1984).

Figure 1 shows the modeled thermal history of a spent fuel waste package and its immediate surroundings. For an unventilated drift the rock at the borehole wall would reach a maximum temperature of $230^{\circ} \mathrm{C}$ at 9 years after package emplacement. The rock temperature $1 \mathrm{~m}$ from the borehole wall would peak at $190^{\circ} \mathrm{C}$ at about $10-20$ years after emplacement. The values of the thermal maxima and the time at which they are attained are sensitive functions of the container power output, the mode of heat transfer, the thermal properties of the near-field rock, and the specific configuration of the boreholes and emplacement drifts. The thermal maximum will be followed by an extended period of cooling which will last for hundreds of years (O'Neal et al., 1984; St. John, 1985).

At the elevation of the repository horizon the unconfined boiling temperature of pure water is $-95^{\circ} \mathrm{C}$. As indicated above, the pore water in the repository rock is likely to be a dilute aqueous solution. Although concentration of the solute species may occur during dehydration and/or rehydration, elevation of the boiling temperature is slight $\left(<1.0^{\circ} \mathrm{C}\right)$ even for solutions that are as much as one hundred times more concentrated than I-13 water (DePoorter, 1986; Montan, 1986). Such solutions exceed the maximum concentration expected for solutions in the waste package environment (Braithwaite, 1985). Vaporization of unconfined pore fluid can therefore be assumed to occur at $-95^{\circ} \mathrm{C}$. This phenomenon will result in the development of a dehydration zone around the waste package, the width and duration of which will depend on the migration behavior of the boiling point isotherm. The model presented in Fig. 1 suggests that during the period of substantially complete containment, which will last at least three hundred years, rock within $1 \mathrm{~m}$ of the spent fuel waste packages will be at temperatures in excess of the boiling point and will therefore be in the dehydration zone.

The scenario for the thermal evolution of the near-field waste package environment is derived from computer codes for which some uncertainties remain to be resolved. The scenario assumes that the waste package being modeled resides in the interior of a repository. Waste package environments along the perimeter of a repository will have a thermal history different from that depicted in Fig. 1. The nature of the thermal history along the perimeter of the repository has yet to be defined. The codes assume no nonlinear effects in the near-field and do not consider the effect of pore water vaporization. The histories presented in Fig. 1 must thenefore be considered approximations of the actual thermal field that will be attained in the waste package environment for a central portion of the repository. The greatest uncertainties pertain to the environment immediately adjacent to the borehole wall where nonlinear effects are expected to be most pronounced (St. John, 1985). Beyond a few meters from the borehole wall computed results are expected to closely represent the actual thermal history for the set of specified conditions.

\section{Thermal Effects on Rock Physical Properties}

The primary effect of thermal loading on the near-field rock will be a change in rock volume due to isobaric thermal expansion. With the exceptions of quartz and cristobalite, the isobaric thermal expansion of most silicate minerals, on average, is $3 \times 10^{-3} \mathrm{cc} /{ }^{\circ} \mathrm{C}$ (Helgeson et al., 1978). The maximum temperature attained by the nearfield environment in the modeling studies results in a total volume change of about $1 \%$ for these phases. This volume change is inconsequential for the waste package environment parameters considered in this report.

Cristobalite, which is present in the near-fjeld environment, undergoes a structural transition from tetragonal ( $\alpha$-cristobalite) to cubic ( $\beta$-cristobalite) symmetry. This phase transition results in a volume increase of about $5 \%$ (Helgeson et al., 1978). The temperature at which this phase transition occurs has been measured for naturally occurring cristobalite at Yucca Mountain (Wolfsberg and 


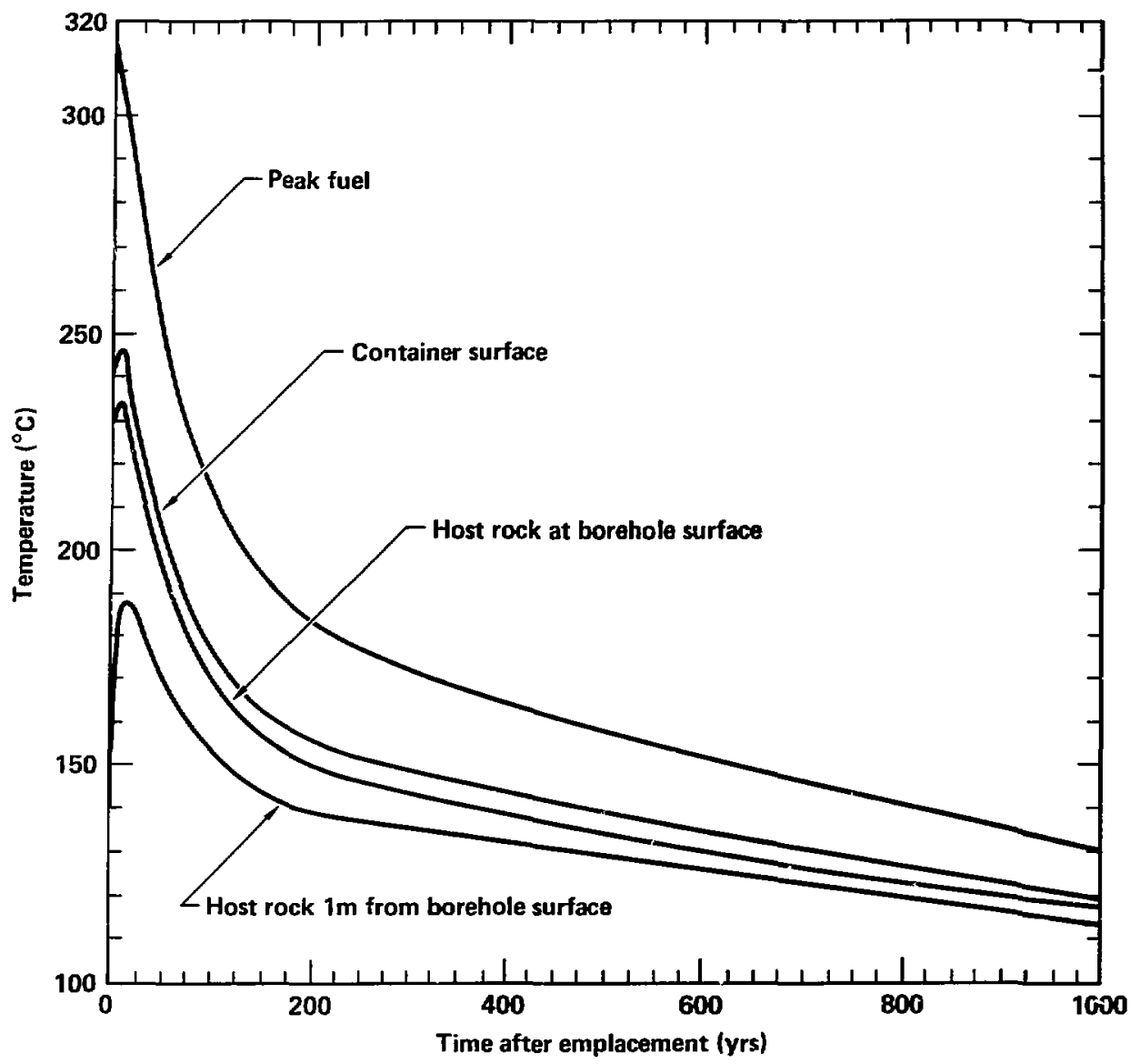

Waste form - Spent fuel (pressurized water reactor)

Local power density - $57.0 \mathrm{~kW} / \mathrm{acre}$

Aerial power density - $48.4 \mathrm{~kW} / \mathrm{acre}$

Average package power at burial $-3.3 \mathrm{~kW}$

(10 yrs out of reactor)

Container diameter $-0.7 \mathrm{~m}$

Package diameter $-5 \mathrm{~m}$

Drift spacing - $\mathbf{4 6 . 8 6} \mathrm{m}$

Directory No. - P57V3.3A

Figure 1. Temperature histories of waste package components and host rock for vertically emplaced spent fuel containers, based on the specified initial conditions ( $O^{\prime} \mathrm{Neal}$ et al., 1984). 
Vaniman, 1984) and has been found to be $225 \pm$ $25^{\circ} \mathrm{C}$. Within the experimental uncertainty this temperature is in agreement with that obtained by other laboratories.

The alpha to beta cristobalite transition temperature falls within the temperature range ex- pected for the near-field waste package environmen! during the period immediately following emplacement. The effect of the associared volume change on the waste package environment has yet to be established.

\section{Radiation Field Effects}

Radiation that interacts with the rock-watervapor system will be neutron and gamma radiation; alpha and beta radiation will not penetrate the waste container (Van Konynenburg, 1984). Gamma radiation will dominate over neutron radiation by more than four orders of magnitude (Wilcox and Van Konynenburg, 1981). While the container remains intact the dominant radiation effects in the waste package environment will be limited to interaction of gamma radiation with water, steam, and air, since gamma radiation has a negligible interaction with rock (Durham et al., 1985). Less than $3 \%$ of the total thermal energy released by the waste package wili be deposited in the host rock by gamma radiation (Van Konynenburg, 1984).

The radiolysis products significant for the waste package environment will vary through time as the thermal conditions evolve. The thermal history of rock adjacent to the waste packages will be complex (Fig. 1). Vaporization of the pore water will occur in rock immediately adjacent to the waste packages where the temperature exceeds $\sim 95^{\circ} \mathrm{C}$. The width of the denydration zone will depend on the magnitude of the thermal load imposed by the waste package on the host rock. While the rock temperature exceeds $95^{\circ} \mathrm{C}$ and the dehydration zone extends more than about $1 \mathrm{~m}$ into the rock surrounding the waste package, radiolysis products will be restricted to those resulting from interaction of gamma radiation with moist air.

Radiolysis products expected in the moist air system, although known to be temperature dependent, are not well established (Van Konynenburg 1986). Theoretical and experimental analysis of a tuff-water-steam system, and consideration of the thermodynamic properties of radiolytic products (Forsythe and Giaque, 1942; Jones, 1959; Beittie, 1967; Van Konynenburg, 1986), suggest that at temperatures below $\sim 120^{\circ} \mathrm{C}$ the most abundant products are $\mathrm{HNO}_{3}, \mathrm{~N}_{2} \mathrm{O}$, and a small amount of $\mathrm{O}_{3}$. Between $\sim 120$ and $\sim 135^{\circ} \mathrm{C} \mathrm{NO}, \mathrm{N}_{2} \mathrm{O}_{4}, \mathrm{~N}_{2} \mathrm{O}$, and $\mathrm{O}_{3}$ are the dominant chemical products, and above $\sim 135^{\circ} \mathrm{C}$ the dominant product species are NO, $\mathrm{N}_{2} \mathrm{O}$, and $\mathrm{O}_{3}$. How these compounds will interact with rock in the waste package environment remains to be established.
In the plesence of liquid water and air the radiolysis products depend on the concentration of solutes and on the radiation dose. Solute concentrations on the order of $10^{-3}$ to $10^{-2} \mathrm{M}$ are obtained in J-13 water that has equilibrated with tuff. These corlcentrations are sufficient to dominate reaction relationships, leading to a small but detectable increase in hydrogen and oxygen pressure due to decomposition of water at high $\left(>10^{5}\right.$ rads/h) radiation levels (Van Konynenburg 1986). Under these conditions a small amount of nitrite and nitrate ions will be produced in solution. The nitrite-nitrate ratio will depend on the abundance of materials that catalyze the breakdown of $\mathrm{H}_{2} \mathrm{O}_{2}$ (e.g., ferric iron and manganese oxide). Addition of hydrogen ion to the solution will also occur, but not in abundances that would exceed the buffering capacity of the bicarbonate available in J-13. Thus there would be little change in the solution $\mathrm{pH}$.

The chemical effects of the radiolysis products on dehydrated waste package environment host rock will be limited to oxidation of mineral phases containing elements having variabie valence states. The principal reactions will involve biotites, amphiboles, and oxides, which individually occupy less than 0.1 vol\% of the rock. The reaction products are expected to be various oxide phases, but little information is currently available on experimental studies relevant to this system. At any given temperature the degree of oxidation will depend on reaction kinetics and concentrations of the oxidizing species, neither of which can be quantified at this time.

By the time rehydration of the host rock occurs within $1 \mathrm{~m}$ of the waste package, the gamma radiation flux will have decayed to levels three orders of magnitude below initial emplacement values (Oversby, 1984a; Baxter, 1983). Radiolysis products will be diminished by approximately a similas magnitude, resulting in concentrations of $\sim 10^{-6} M$ or less (Van Konymenburg, 1986). Within the rock this will result in insignificant modification of mineral and fluid chemistry. 


\section{Thermal Effects on Water Flow in the Vicinity of Waste Packages}

Our present level of understanding of the ambient hydrologic system at Yucca Mountain has been discussed by Montazer and Wilson (1984) and Ortiz et al. (1985). These papers show that the potential repository horizon is located within a nonlithophysal unsaturated zone several hundred meters above the water table.

Water transport within this rock occurs by a combination of vapor transport, water migration through the matrix, and fracture flow (Montazer and Wilson, 1984). The relative importance of each flow mechanism is a function of the degree of saturation of the pores, the volume of water being transported, the temperature gradients in the rock, and the permeability of the matrix. It has been established that the fracture density within this lower nonlithophysal zone varies between 8 and 40 fractures $/ \mathrm{m}^{3}$ (Scott et al., 1983), with a mean matrix porosity of $14 \%$ (56 samples, with a standard deviation of 5.5) and a mean saturation of $65 \%$ (44 samples, with a standard deviation of 19) (Montazer and Wilson, 1984).

The net flux of water through the repository is probably 1.0 to $2.0 \mathrm{~mm} / \mathrm{yr}$ upward, although a downward flux of $0.1 \mu \mathrm{m}$ to $0.5 \mathrm{~mm} / \mathrm{yr}$ may occur as a result of matrix flow (Montazar and Wilson, 1984; Montazar et al., 1985). The current matric potential of the Topopah Spring tuff is approximately $-112 \mathrm{kPa}$, which results in negligible fracture flow (Wang and Narasimhan, 1985). Fracture saturation will not exceed 0.01 unless the matrix is fully saturated and the matric potential is in the range of -1 to $-0.01 \mathrm{kPa}$, which is two to three orders of magnitude greater than at present (Wang and Narasimhan, 1985). Precise statements regarding when fracture flow would become dominant cannot be made until more information is available about other fracture characteristics, including fracture roughness.

The emplacement of waste packages in the rock would produce a large thermal perturbation. This in turn would cause water to vaporize and migrate in the near field and would result in an altered hydrologic regime. There is very little information, either experimental or theoretical, on thermally driven flow in partialiy saturated rocks. Because water is the main corrosive agent for the metal containment barrier and the main transport agent for radionuclides, experimental and modeling studies have been initiated to characterize fuid flow and the geochemistry of water-rock interactions in the Topopah Spring tuff.

The fluid flow experiments (Lin and Daily, 1984; Daily and Lin, 1986) were designed to inves- tigate the mechanism of dehydration and rehydration under a variety $i$ thermal conditions in fully saturated intact and fractured rock. Experiments in unsaturated tuff are under development. The results described below are from fully saturated samples.

These studies were carried out in two stages. The initial stage involved reconnaissance experiments in which electrical resistivity measurements and $P$-wave velocity measurements were evaluated as means of mapping fluid distribution in the rock during dehydration-rehydration cycles at various temperarures (Lin and Daily, 1984). These experiments allowed initial characterization of the hydrologic properties of the tuff during dehydration and rehydration. The second stage of the study involved development and use of computed impedance tomography (CIT) to obtain detailed images of fluid distribution in the tuff during dehydration-rehydration cycles (Daily and Lin, 1986). In both stages steam and water permeabilities were determined for fractured and unfractured (intact) samples of tuff.

In the initial stage of this study three samples of tuff were used in the experiments. Two samples of Topopah Spring 'uff from Fran Ridge (Knauss, 1984) ard one sample from drill core USW G-1 were machined to form right cylinders $9.0 \mathrm{~cm}$ long and $2.54 \mathrm{~cm}$ wide. One of the Fran Ridge samples was intact while the remaining samples each had one longitudinal fracture.

Four pairs of electrical resistance measuring electrodes were placed along the axis of each sample to generate resistivity maps. Transducers to measure P-wave velocity were mounted on the ends of the samples and the samples were jacketed in Viton to provide isolation of the rock from the confining pressure medium. Electrical resistivity and $P$-wave velocity were monitored during dehydration and rehydration of the samples to provide information on the geometry of water flow during the experiments. All experiments were conducted with a confining pressure of 5.0 MPa. Fluid flow rate was measured at several temperatures and was used to calculate permeability for the samples. In order to mimic as closely as possible the in situ pore fluid chemistry, $\mathrm{J}-13$ water was used as the aqueous phase in these experiments. The protocol for the initial experiments and the results of permeability measurements are summarized in Lin and Daily (1984).

The resistivity images obtained during dehydration and rehydration of the intact sample showed that during rehydration and dehydration 
fluid flowed uniformly through the rock; there were no preferred flow paths. In addition, the permeability of this unfractured rock was independent of temperature and thermal history. These results are consistent with those reported by Morrow et al. $(1981,1985)$ and suggest that the hydrologic properties of unfractured rock in the waste package environment will not be modified by the anticipated thermal perturbation.

The behavior of the fractured sample was in striking contrast to that of the intact sample. The initially high permeability decreased by more than three orders of magnitude to values indistinguishable from that of the intact sample during successive cycles of dehydration and rehydration (Table 3). In addition, the initial dehydration occurred eight times faster than in the intact sample. The rate at which drying occurred suggests that dehydration was controlled by fluid flow along the fracture.

Healing of the fracture by deposition of silica during fluid flow appears to be responsible for the change in permeability. Prior to the experiment the fracture was open, but upon completion of the experiment the iwo fragments of rock were bonded together. Scanning electron mictoscope images of the healed fracture surface showed multiple layers of silica deposited on the fracture walls (Lin and Daily, 1984?.

In onder to isolate the main factors contributing to fracture healing, the fractured sample from USW G-1 was subjected to a sequence of thermal cycles under conditions of constant saturation. Preparation of the sample was the same as for the earlier samples except for the placement of the electrodes. Surface conditions of the fracture were closely similar to those of the fracture in the outcrop sample. Initial room temperature permeability was $\mathbf{6 0 0}$ to $\mathbf{7 0 0}$ microdarcies, decreasing to $\mathbf{3 5 0}$ microdarcies after a day under flowing conditions. Upon heating the sample to $96^{\circ} \mathrm{C}$ under saturated conditions, the permeability decreased by an order of magnitude. Changes in temperature up to $140^{\circ} \mathrm{C}$ and back to room temperature did not produce any further large changes in permeability. Examination of this sample after the end of the experiment showed that fracture healing had occurred, but to a lesser extent than in the first sample.

Resistivity maps document that the rate of change of resistivity is much greater for the fractured samples than for the intact sample. This is

Table 3. Behavior of fractured and unfractured samples in permeability experiments on Topopah Springs tuff (Lin and Daily, 1984).

\begin{tabular}{|c|c|c|c|}
\hline \multirow{2}{*}{\multicolumn{2}{|c|}{ Sequence of experimental procedures }} & \multicolumn{2}{|c|}{$\begin{array}{l}\text { Measured permeability } \\
\text { (in microdarcies) }\end{array}$} \\
\hline & & $\begin{array}{l}\text { Inlact } \\
\text { sample }\end{array}$ & $\begin{array}{l}\text { Fractured } \\
\text { sample }\end{array}$ \\
\hline 1. & Determine permeability at $21^{\circ} \mathrm{C}$ & 0.34 & 850 \\
\hline 2. & Dehydrate* at $140^{\circ} \mathrm{C}$ & & \\
\hline 3. & $\begin{array}{l}\text { Rehydrate with liquid water at } 140^{\circ} \mathrm{C} \text {, with differential pressure } \\
\text { of } 2.5 \mathrm{MPa}\end{array}$ & & \\
\hline 4. & Determine liquid water permeability at $140^{\circ} \mathrm{C}$ & 0.31 & $40,34^{b}$ \\
\hline 5. & Dehydrate ${ }^{2}$ at $140^{\circ} \mathrm{C}$ & & \\
\hline 6. & $\begin{array}{l}\text { Rehydrate with steam at } 140^{\circ} \mathrm{C} \text { with differensial fluid pressure of } \\
0.2 \mathrm{MPa}\end{array}$ & & \\
\hline 7. & Determine steam permeability at $140^{\circ} \mathrm{C}$ & 1.99 & 3.9 \\
\hline 8. & Dehydrate at $140^{\circ} \mathrm{C}$ & & \\
\hline 9. & $\begin{array}{l}\text { Rehydrate with liquid water at } 98^{\circ} \mathrm{C} \text {, with differential fluid } \\
\text { pressure of } 2.5 \mathrm{MPa}\end{array}$ & & \\
\hline 10. & Determine liquid water permeability at $98^{\circ} \mathrm{C}$ & 0.35 & 0.24 \\
\hline
\end{tabular}

The confining pressure was $5 \mathrm{MPa}$. Rehydration and permeability measurements were conducted by applying the indicated pressure to one end of the sample.

' Dehydration was accomplished by drying the sample in the pressure vessel, with both ends of the sample exposed to the atmosphere.

${ }^{b}$ The value of 34 microdarcies was measured after cooling the sample to $98^{\circ} \mathrm{C}$. 
consistent with the interpretation that dehydration occurs musch more rapidly in the fractured sample. The distribution of resistivity along the fracture surface was not uniform, suggesting that fluid migration along the fracture surface does not take place at a uniform rate. "This behavior contrasts with that deduced from resistivity maps of the intact sample that document aniform resistivity changes ar,d, consequently, uniform fluid flow.

Attempts to use $P$-wave velucity measurements to characterize fluid iniw did not provide sufficient resolution to be useful. Although changes in $\mathbf{P}$-wave velocity could be measured during various stages of the deliydration and rehydration cycles, complex variation in the measured velocity make interpretation of the results difficult.

These initial results suggested that fluid flow in fractured rock at elevated temperatures would lead to a decrease in permeability of an order of magnitude or more. Dehydration rates were significantly faster for fractured material compared to dehydration rates obtained on intact samples.

The second experimental stage was designed to more thoroughly characterize the fracture flcw process by using CIT to obtain higher resolution resistivity images (Daily et al., 1986). In these experiments 14 electrodes were attached to the circumference of a fractured sample, approximately perpendicular to the plane of the fracture. Four electrode pairs were also attached parallel to the long axis of the core samples as in the previous experiments. The resulting resistivity maps provide a cross-sectional image of fluid distribution in the core as well as low-resolution images parallel to the long axis of the core. Permeability measurements obtained simultaneously with the CIT images allow correlation of permeability changes with changes in fluid distribution in the core. The experimental protocol in this second set of experiments was similar to that used during dehydrationrehydration cycles for the first fractured core sample (Daily et al., 1986).

The results of these experiments (Daily et al., 1986) are consistent with the previous results. Rapid decrease in permeability occurred during dehydration stages (Fig. 2), resulting in permeability changes of more than three orders of magnitude. The final permeability obtained at the end of the experiment was indistinguishable from that obtained previously on intact samples.

The CIT images (Fig. 3) suggest that the aperture of the fracture decreases during the course of the experiment. Soth images in Fig. 3 were taken $24 \mathrm{hr}$ after drying at $135^{\circ} \mathrm{C}$. Image I130B was

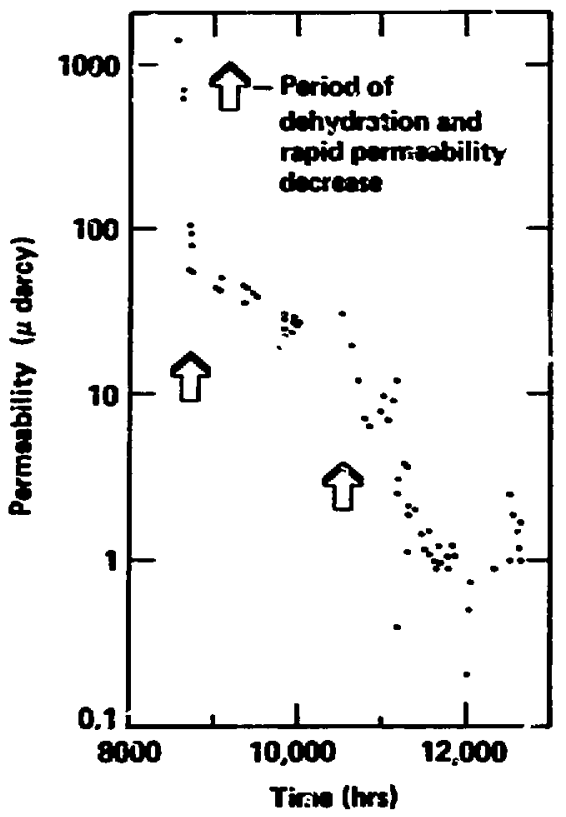

Figure 2. Fluid permeability (in microdarcies) for fractured Topopah Spring tuff versus time in hours from January 1, 1904, when the experiment was started. The rapid decreases in permeability occurred dwring the first and wecond second dehydration.periode at about 9,000 and 11,(00) hour (see Tzble 3). Upstream pore water presure was 0.1-0.3 MPa; sample diameter was $8.23 \mathrm{cn}$.

taken during the second drying cycls, while image $16 i 5$ was taken during the fourth drying cycle. In both samples the matrix is saturated except in the vicinity of the fracture. In image $1130 \mathrm{~B}$ drying along the entire fractuic length is apparent, suggesting uniform: ventilation along the fracture. In image is15, the upper left portion of the fracture exhibits resistivity values only slightly higher than that of the matrix, while the remainder of the fracture has dried in a fashion similar to that in image I130B. This result suggests that the aperture of the fracture in the upper left of the image has been substantially diminished, restricting ventilation and resulting in a decreased rate of dehydration. These observations are consistent with the interpretation of the previous studies that healing along the fracture during dehydration-rehydration 


\section{I130B}
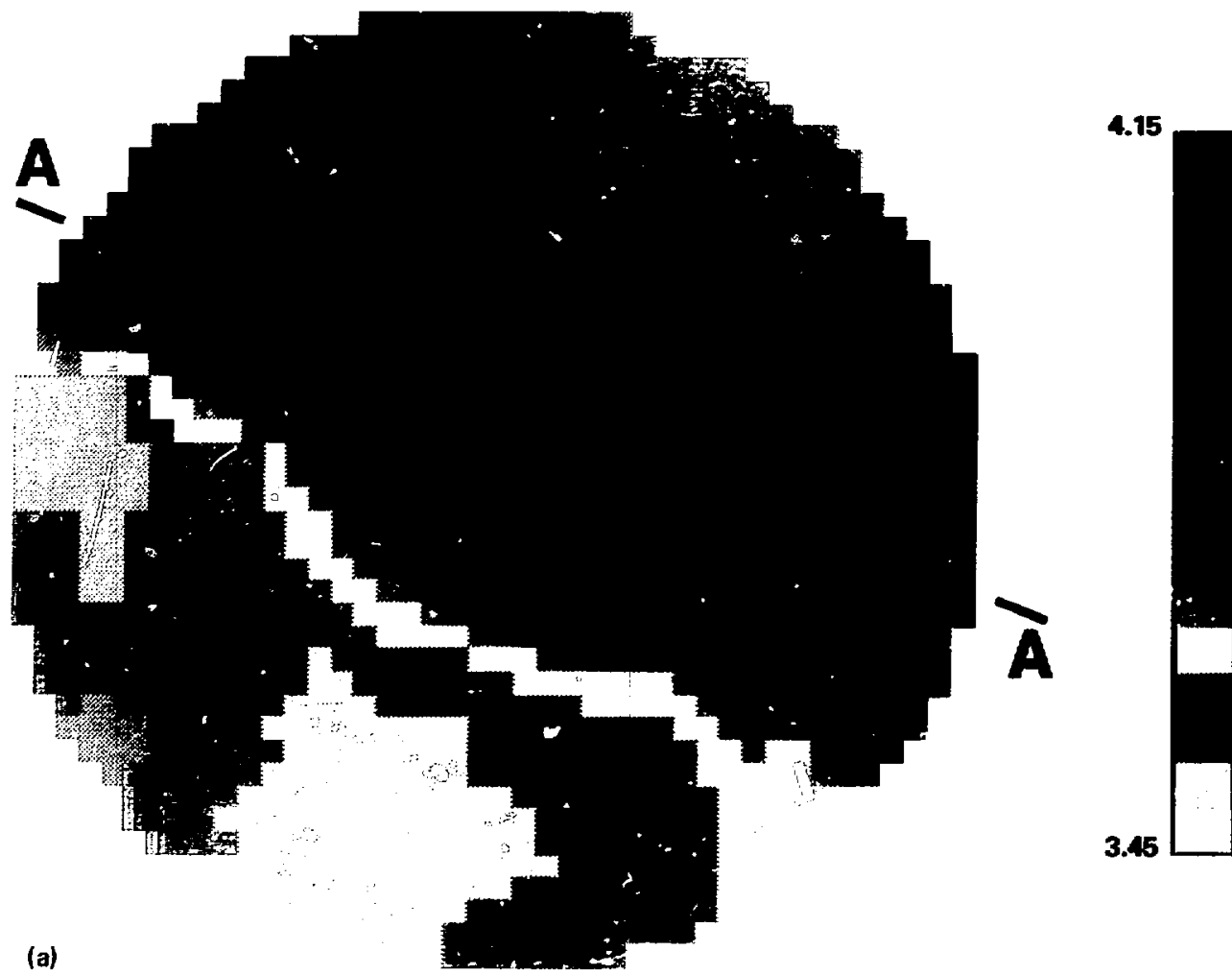

Figure 3. Computed impedance tomozraphs of a fractured sample of Topopah Spring tuff. The lines A-A and B-B identify the fracture. Resistivity is color-coded, with black representing the dryeat regions (highest resistivity) and white representing the wettest regions (lowest resistivity). Figure $3:$ a) shows the fractured sample during the second drying cycle. Note the decrease in apparent width of the same fracture in Figure $3(b)$, an image taken during the fourth drying cycle. 


\section{5}

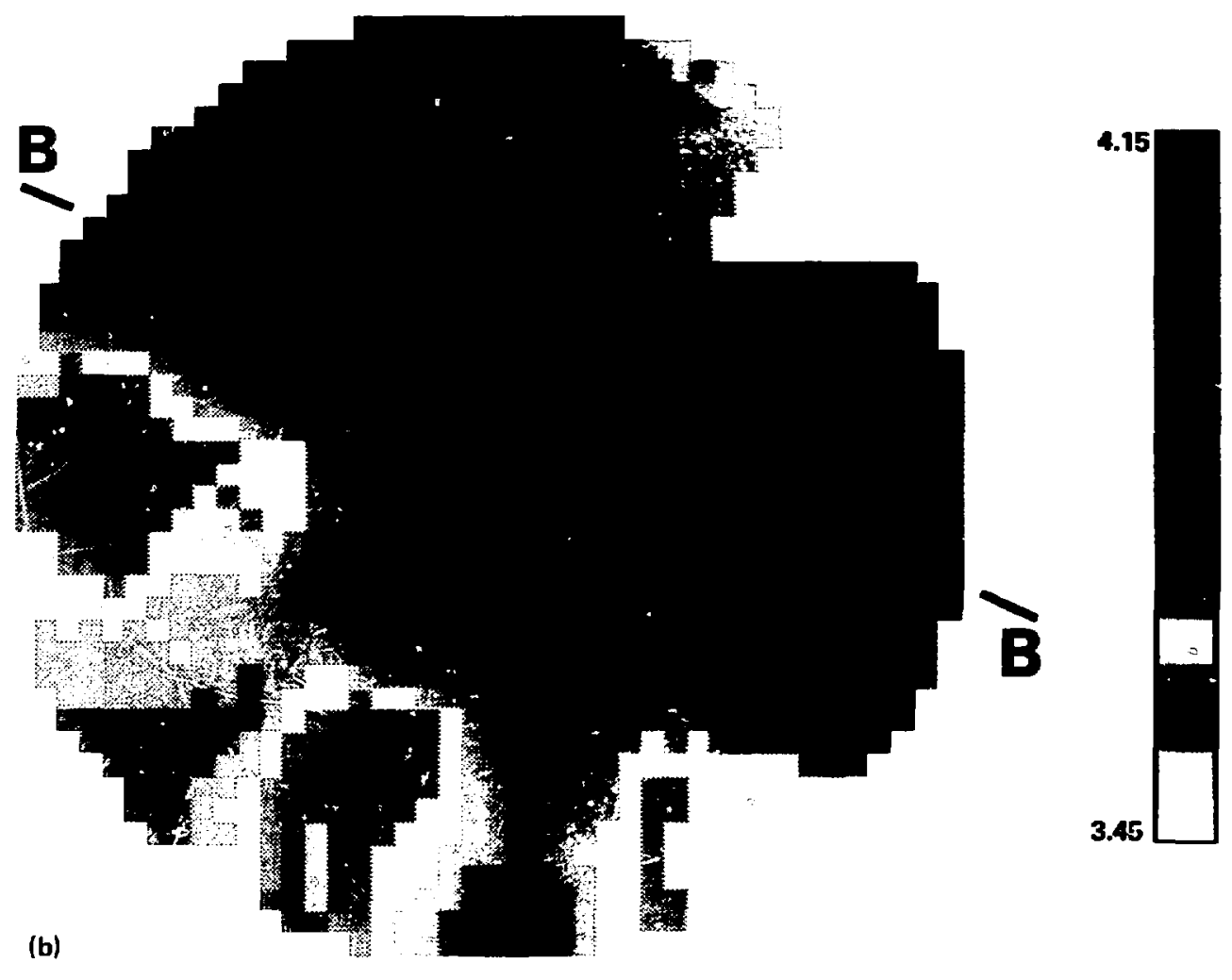

Figure 3. (Continued). 
cycles is responsible for the drop in permeability observed in the experiments using fractured samples.

These initial results demonstrate that the hydrologic properties of intact rock will not be modified by dehydration/rehydration cycles resulting from the thermal load imposed on the waste package environment by the waste containers. Uniform fluid flow under post-emplacement conditions can be expected. The hydrologic properties of fractured samples in a thermally perturbed environment may be sensitive to solution/deposition processes. The mechanism responsible for this behavior is unknown and the behavior in a two-phase system has not been characterized. Further work is planned to address these questions. Completion of the planned work will allow evaluation of the implications of the fracture healing process.

\section{Rock-Water Interactions}

The elemental composition and ionic speciation of constituents dissolved in water may have a significant effect on the corrosive action of the water anu on its ability to dissolve and transport radionuclides. Factors that irfluence the nature and concentration of dissolved constituents include the mineralogy of the rock in contact with the water, the temperature at which the contact takes place, the duration of the contact, and the volume ratio of rock to water. The last two parameters are most important for interpretation of kinetically-controlled dissolution and precipitation reactions. Performance assessment requires knowledge of these parameters in order to establish corrosion behavior of the waste package under a variety of scenarios and to evaluate radionuclide transport.

The flow rate of water in the unsaturated zone is uncertain. Infiltration rates deduced for the potential repository horizon matrix vary from $0.1 \mu \mathrm{m}$ to $0.5 \mathrm{~mm} / \mathrm{yr}$, although a net upward vertical transport may also occur (Montazer and Wilson, 1984; Montazar et al., 1985). Fracture flow rates are unknown. The matrix flow rates would result in long contact times between rock and water. Flow through fractures may be slow or rapid depending on the fracture aperture and the water flux. To cover the range of possible conditions a number of tests have been conducted to determine the changes in water chemistry for a variety of contact times, rock surface-area-to-water volume ratios, temperatures, and a range of rock samples representative of the Topopah Spring tuff.

Rock-water interaction studies have been conducted using three main experimental methods:

1. Solid core wafers or crushed tuff reacted in gold-bag rocking autoclaves (Dickson bombs);

2. Solid core wafers or crushed tuff reacted in Teflon capsules contained in steel casings (Parr acid digestion bombs);

3. Solid core wafers or crushed tuff reacted in stainless steel vessels.
Each of these methods has advantages and limitations. However, by combining data from all three methods the artifacts of experimcntal technique can be removed from the data and a better estimate of the chemistry of the water under in situ conditions can be obtained.

The gold-cell autoclaves allow sampling of fluids to be performed without quenching the run. The gold bag is inert and impervious, providing a nonreactive container that is gas tight. This feature is important because carbon dioxide is a reactant of interest in the system. The disadvantages of the gold-cell autoclaves are that the tests are expensive to run, thereby limiting the amount of data that can reasonably be obtained; the rocking action of the system is not representative of expected repository conditions; and the sampling during reaction causes a change in fluid-to-solic? ratio during the run.

Reactions in Teflon-lined Parr bombs are inexpensive to run witd a large amount of data can be accumulated. The disadvantages of his method are that the Teflon capsule absorbs carbon dioxide from the reacting mixture, thereby affecting the $\mathrm{pH}$ and alkalinity data (Knauss et al., 1984b); the assembly must be cooled to near room temperature before opering and separating the fluid and solid phases; and the Teflon cannot be used in a gamma radiation field because it breaks down radiolytically and contaminates the fluid with hydrofluoric acid. As will be discussed below, the gas absorption effect can clearly be seen in the data, but the cooling to room temperature do s not produce any detectable effects.

For tests conducted in a zamma radiation field stainless steel vessels are used. Corrosion of the vessels is very slight under the reaction conditions, and the effects on solution chemistry are limited to minor amounts of iron, nickel, and chromium being added to the solutions.

The Topopah Spring tuff occurs in outcrop at Fran Ridge. Because many of the waste package 
materials interaction tests require rather large ancounts of rock, the outcrop material has been characterized to determine whether it can be used in experiments and tests that require more rock than can be obtained readily from the drill core (Oversby and Knauss, 1983; Oversby, 1984a). The petrologic characterization of the outcrop showed that there were no significant aifferences between that material and samples obtained from the ن $3 W$ G-1 drill core (Knauss, 1984). There is a difference between the outcrop and drill core material with respect to rock-water interaction chemistry. The outcrop material contains a readily soluble component that appears to be due to evaporation of surface runoff water from the pores, leaving behind significant amounts of previously dissolved salts. The principal constituents of these salts are ca: um, sodium, potassium, chloride, nitrate, sulfite, and boron (Oversby, 1984a,b). The sali deposits are found only in near-surface samples and are not present in samples collected some distance from the surface (Oversby, 1985).

The choice of rock sample form is dictated by the type of data needed from the tests. If characterization of secondary phases and alteration products is required, it is necessary to use polished wafers of solid rock that are suitable for examination by surface analysis techniques after completion of the tests. Crushed rock is used if the desired information concerns the effects of rock surface-area-to-water volume ratio on final chem:istry because the weight added to the system can tie more easily controlled.

Studies involving secondary phase characterization used rock wafers $2.54 \mathrm{~cm}$ in diameter by $0.25 \mathrm{~cm}$ thick prepared from irill cores. One side of each wafer was hand-polished to allow examination by electron microscopy. The tests conducted at $150^{\circ} \mathrm{C}$ in gold-cell autoclaves will be described in some detail, while those conducted at $250^{\circ} \mathrm{C}$ will be mentioned where they provide additional information to that obtained at the lower temperature. During the course of the investigations samples of fluid were removed periodically without interrupting the course of the reaction. The samples were analyzid for $\mathrm{pH}$, dissolved carbonate species, cations, and anions. By the end of the reaction period the fluid volume in the autoclave cell was about half that at the start of the reaction. At the end of each test the rock wafer was removed from the autoclave, rinsed with distilled water, dried, and carbon coated for examination of phases by scanning electron microscopy (SEM) and electron microprobe analysis (EMP).
All cation analyses were conducted on acidified, filtered (0.1 $\mu \mathrm{m}$ Nucleopore filters) samples. Anion analyses were conducted on filtered samples. Unmodified samples were used for all $\mathrm{pH}$ measurements.

The results of tests carried out at 150 and $250^{\circ} \mathrm{C}$ in gold-cell autoclaves using rock wafers prepared from USW G-1 drill core have been published by Knauss et al. (1984a). Results from goldcel! tests at 90,150 , and $250^{\circ} \mathrm{C}$ using crushed USW G-1 material are reported in Knauss et al. (1985a). Long-term studies ( -300 days) at 90 and $150^{\circ} \mathrm{C}$ are reported in Knauss et al. (1986). Parr bomb data have been published for reaction temperatures of 90,120 , and $150^{\circ} \mathrm{C}$ (Oversby, 1984a,b). These tests used rock obtained from an outcrop of Topopah Spring tuff located at Fran Ridge. Results from reaction at $150^{\circ} \mathrm{C}$ in Parr bombs of crushed rock from drill cores USW G-1, USW GU-3, USW G-4, and UE-25h\#1 are contained in the report by Oversby (1985). A description of the outcrop locality and characterization data for the rock sarnples may be found in the report by Knauss (1984). The discussion that follows is drawn primarily from these reports.

The unconfined boiling point of water at the repository elevation would be $\sim 95^{\circ} \mathrm{C}$. Small pores in the rock retain water at somewhat higher temperatures due to capillary forces. Repository scale modeling has indicated that water can be retained in pores at temperatures up to $140^{\circ} \mathrm{C}$ if a restriation on venting is imposed (Travis et al, 1984). Rock-water tests were conducted at $90^{\circ} \mathrm{C}$ in order to represent conditions of near-maximum temperature that are expected for the main mass of water that would flow through rock and potentially contact waste packages. Tests at $150^{\circ} \mathrm{C}$ represent the conditions for small volumes of water retained in pores under unusual but possible conditions. Some tests were conducted at $250^{\circ} \mathrm{C}$ to investigate the nature of secondar: phases formed and to assist in providing kinetics data for reaction path-modeling. Because the secondary mineral assemblage at $250^{\circ} \mathrm{C}$ may be different from that formed at lower temperatures, these data shou!d be used only to guide the direction of lower temperature studies until a direct tie to lower temperature phase assemblages can be established.

Solution analysis data for the core wafer experiments at $150^{\circ} \mathrm{C}$ are plotted in Figs. 4 (silicon and sodium) and 5 (aluminum, potassium, calcium, magnesium, and $\mathrm{pH}$ ). The data were originally reported by Knauss et al. (1984a). The aluminum concentration in solution increased with 


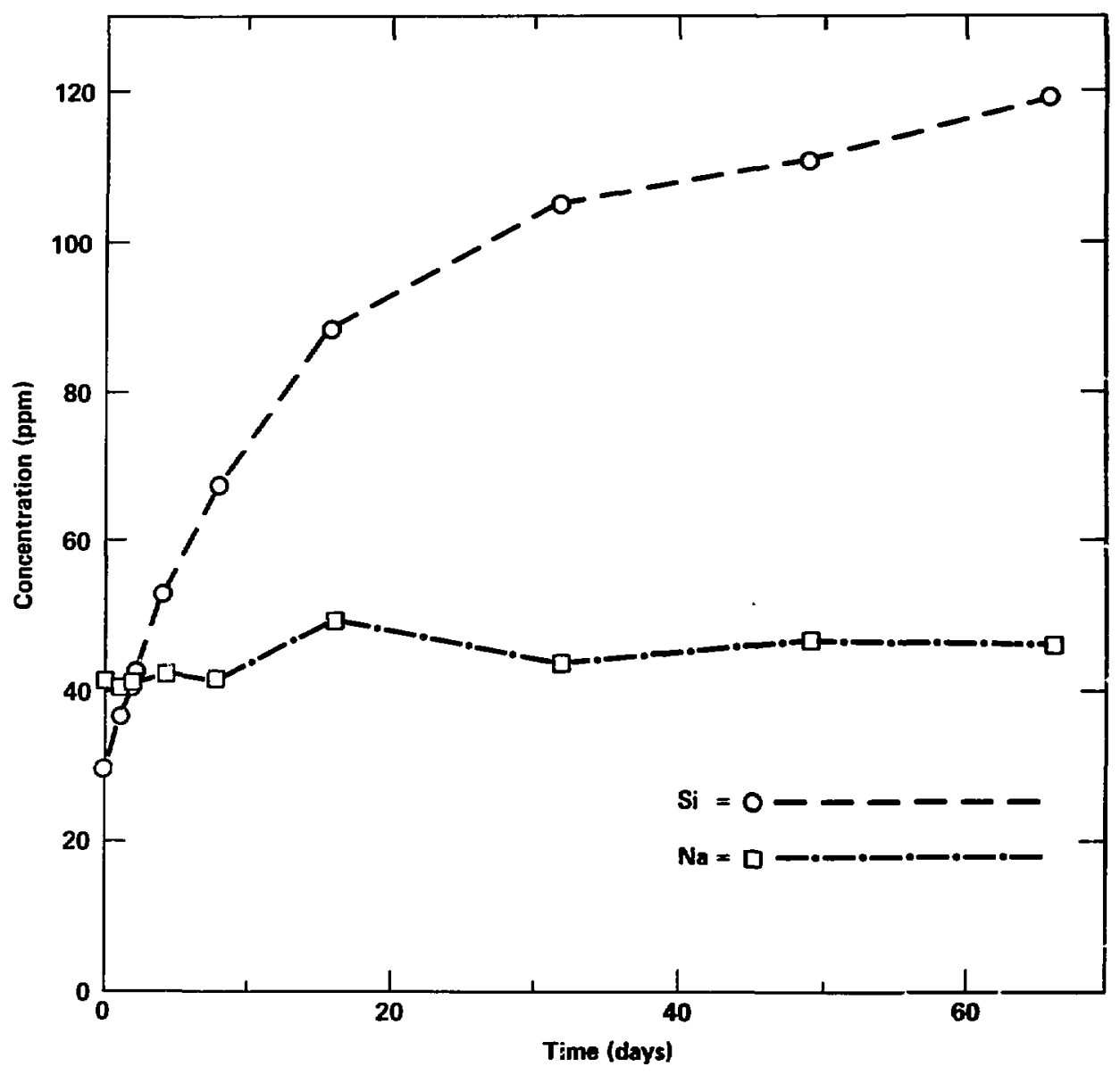

Figure 4. Silicon and sodium concentrations in J-13 water reacted with G-1 core wafers at $150^{\circ} \mathrm{C}$ as a function of time in days (Knauss et al., 1985b).

reaction from the originally low $\mathrm{J}-13$ value of $0.01 \mathrm{ppm}$ to reach a maximum of $1.2 \mathrm{ppm}$ within a few days. As the reaction proceeded the aluminum concentration dropped slowly, reaching $0.5 \mathrm{ppm}$ by the end of the run. This behavior suggests supersaturation of aluminum with respect to smectite followed by kinetically-inhibited precipitation. Modeling of rock-water systems, discussed below, supports this suggestion. Silicon increased fairly rapidly in the early portions of the test and then more slowly. By the end of the reaction interval silicon had reached about $120 \mathrm{ppm}$, near the solubility of cristobalite. The slope of the data versus time suggests that saturation had not yet been reached for silicon.

Calcium concentration decreased from 12 to about $8 \mathrm{ppm}$ in the first cay of reaction and then decreased slowly to a final value of $6 \mathrm{ppm}$ at the end of the reaction time Magnesium, initially present at $1.9 \mathrm{ppm}$, was essentially removed from solution during the first day of reaction. The behavior of potassium resembled that of aluminum with an initial increase from the $\mathrm{J}-13$ value of $4.6 \mathrm{ppm}$ to a maximum of $6.5 \mathrm{ppm}$ followed by a 

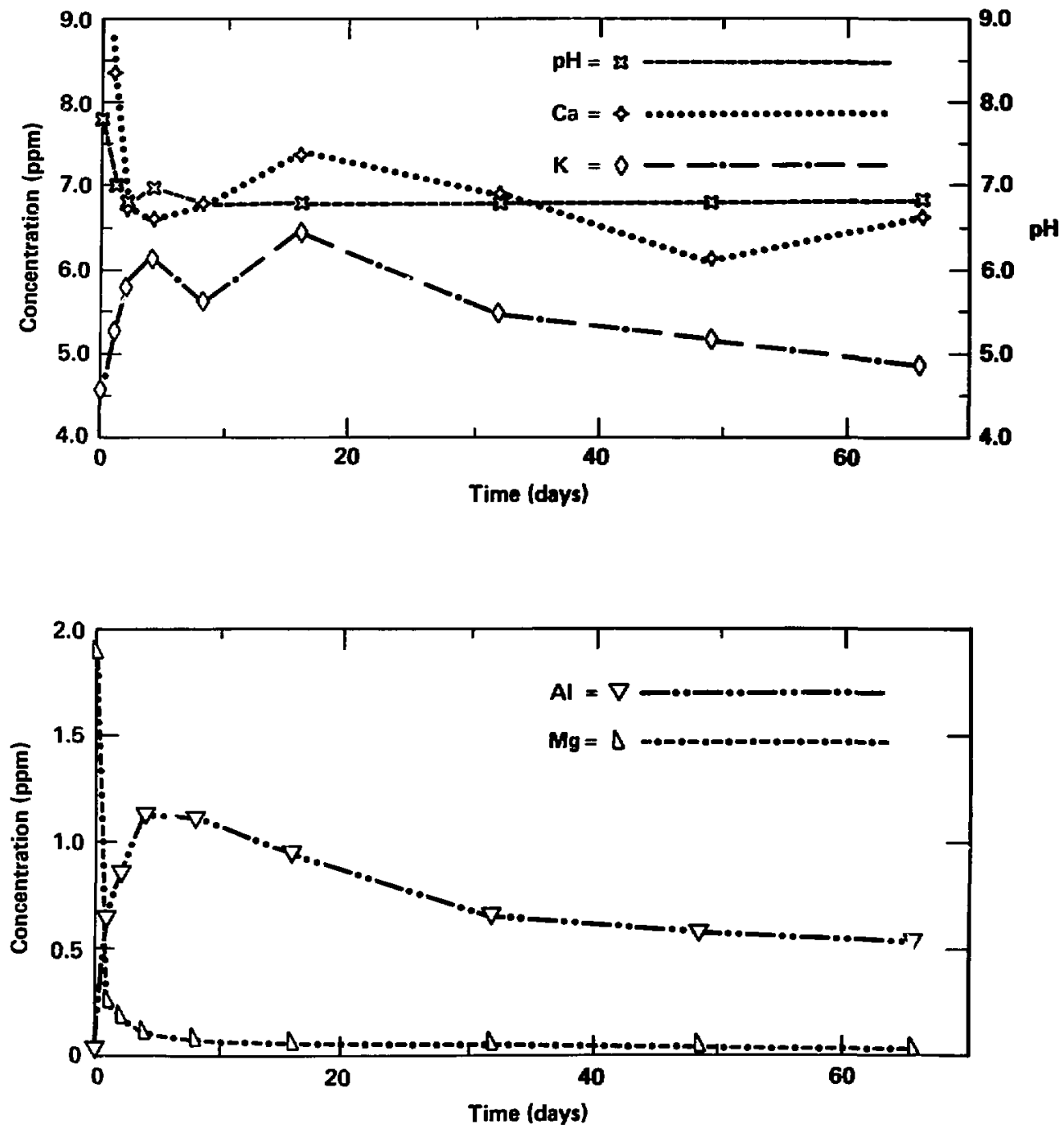

Figure 5. Aluminum, potassium, calcium, magnesium, and pH analyses of J-13 water reacted with G-1 core wafers at $150^{\circ} \mathrm{C}$ as a function of time in days (Knauss et al., 1985b). 
gradual decrease as the reaction proceeded. The $\mathrm{pH}$ of the solution as measured at room temperature showed a slight immejiate decrease to 6.8 and remained constant thereafter. The sodium concentration appears to have increased slightly, but the difference between initial and final values is within the precision of the analyses. Data for anions showed no significant changes from the initial J-13 values for fluoride, chloride, nitrate, and sulfate, and a slight decrease in dissolved carbonate content.

The core wafers were examined after a 66day reaction period to determine the extent of alteration of the mineral phases. Plagioclase feldspar phenocrysts showed highlighted twinning due to the formation of etch pits on their surface, and biotite showed general corrosion. The smaller sanidine crystals, originally formed by granophyric devitrification of the rock and vapor-phase crystallization in lithophysal cavities, appeared to be particularly prone to hydrothermal attack. The fine-grained devitrification products of the matrix also showed visual evidence of hydrothermal alteration. Quantitative wavelength dispersive analysis of the phenocryst and matrix phases did not show any compositional changes as a result of the reaction, indicating that simple dissolution is the primary mechanism of alteration of the rock during these tests (Knauss et al., 1984a).

SEM observation of the surface of the core wafer was used to study secondary minerals formed at $150^{\circ} \mathrm{C}$. Although identification of these run products is difficult because they are poorly crystalline and non-stoichiometric, estimates of the phases present can be obtained by combining the information obtained from energy dispersive chemical analysis and phase morphology. The analyses indicate that the secondary phases include a potassium rich "clay" (possibly illite); a zeolite rich in magnesium, calcium, and/or iron; gibbsite; calcite; and a pure silicon rich phase (possibly cristobalite; Knauss et al., 1984a, 1985b). Clay minerals are the dominant secondary phases with the abundance of the other phases being much lower. The total amount of secondary phases was quite small.

ldentification of one of the reaction products as the rare zeolite dachiardite was accomplished through use of the $250^{\circ} \mathrm{C}$ runs where the minera! developed in abundances sufficient for characterization (Knauss et al., 1985b). This zeolite was present in several of the runs, occasionally coexisting with mordenite. The dachiardite produced in these experiments was a high-calcium variety, whereas most natural occurrences of the mineral are in different geochemical environments that promote the growth of sodium- and potassiumrich varieties.

Autoclave tests were also conducted at $90^{\circ} \mathrm{C}$; data for solution anzlyses are shown in Figs. 6 and 7 based on a 48-day test period (Knauss et al., 1985b). The solution compositions showed minor changes from the initial $\mathrm{j}-13$ values with a slight increase in potassium and silicon and a small decrease in magnesium. Tests conducted at this temperature for times up to $\mathbf{3 0 0}$ days have recently been completed. The effects of hydrothermal alteration at $90^{\circ} \mathrm{C}$ on the wafer phenocrysts and matrix were very minor. No changes in the composition of the phases as a result of reaction could be detected (Knauss et al.. 1985b). Secondary phases were very rare and were limited to the potassium rich "clay" observed in the experiment at $150^{\circ} \mathrm{C}$ (Knauss et al., 1985b).

A set of autoclave tests was run at 90 and $150^{\circ} \mathrm{C}$ using crushed tuff from USW G-1 core (Knauss et al., 1985a). The crushed rock used in the tests had a surface area as measured by BET that was about 20 times greater than that of the core wafer. Part of the increase in surface area was due to the use of a greater mass of rock in the crushed rock tests. Solution concentrations resulting from kinetically-controlled dissolution reactions are dependent on the surface areas of solid in relation to the volume of solution (SA/V) (Aagaard and Helgeson, 1982; Helgeson and Murphy, 1983). Solution concentrations in different tests can be scaled using the reaction parameter (SA/V)t where $t$ is the reaction time (Lagache, 1965).

Data for solution analyses from the $150^{\circ} \mathrm{C}$ tests with crushed USW G-1 Topopah Spring tuff are shown in Figs. 8 and 9. Detailed analytical results may be found in the report by Knauss et al. (1985a). As expected, the crushed material reacted more rapidly than the core wafer. Solution concentrations of silicon after a few days reached the level achieved at the end of the 66 day core wafer test. The maximum aluminum concentration was higher for the crushed rock than for the core wafer. Precipitation of aluminum silicates was more rapid than for the core wafer experiments. Final solution concentrations were comparable for the two tests. The potassium concentrations showed a pattern similar to that of aluminum, with a rapid rise in solution concentration followed by a slow decrease. Again peak concentration was higher for the crushed material than for the core wafer. Final sodium concentrations were somewhat higher with the crushed tuff as compared to the core wafer, suggesting slow dissolution of alkali 


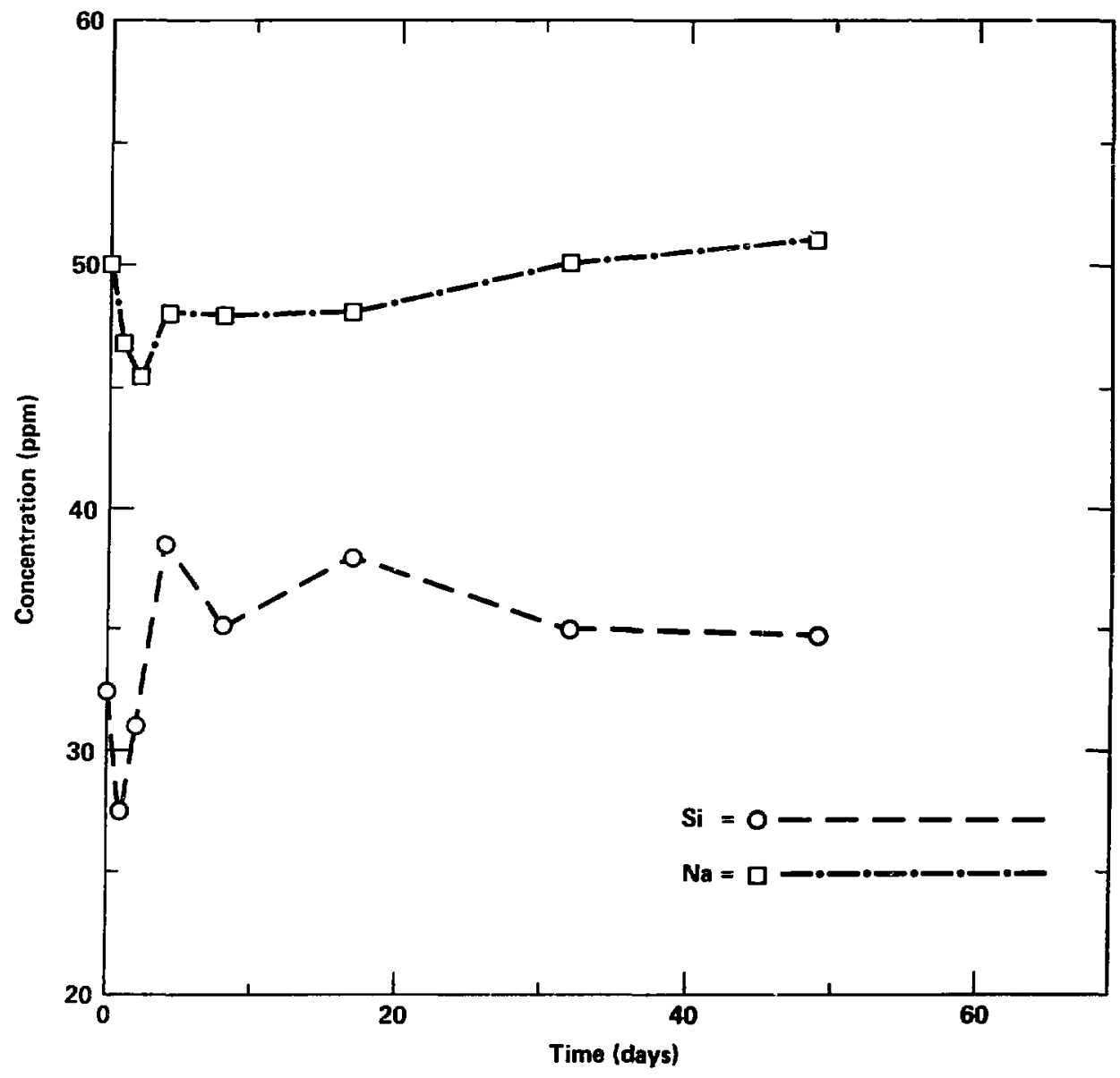

Figure 6. Silicon and sodium concentrations in J-13 water reacted with $\mathrm{G}-1$ core wafers at $90^{\circ} \mathrm{C}$ as a function of time in days (Knauss et al., 1985b).

feldspar. Data for calcium, magnesium, $\mathrm{pH}$, and anions were essentially independent of the physical form of the samples.

The differences between results for crushed rock and core wafer tests at $90^{\circ} \mathrm{C}$ were similar to those seen at $150^{\circ} \mathrm{C}$. Initial changes in concentrations were more rapid with the crushed material. Final silicon concentration reached $\sim 50 \mathrm{ppm}$ after 70 days. The potassium concentration peaked at slightly over $10 \mathrm{ppm}$ and then decreased to about $8 \mathrm{ppm}$, a somewhat higher level than was seen in the core wafer tests.
The only post-reaction solid phase analyses that could be made on the crushed tuff were obtained using $x$-ray diffraction. This technique cannot detect any phase with a concentration below a few percent. As expected, no alteration phases were observed in the XRD spectra (Knauss et al., 1985a).

Long-term (3C4 days) hydrothermal experiments were used to establish the degree to which equilibrium was attained in the experiments described above and to evaluate the effects of precipitation kinetics on phase relationships in the 


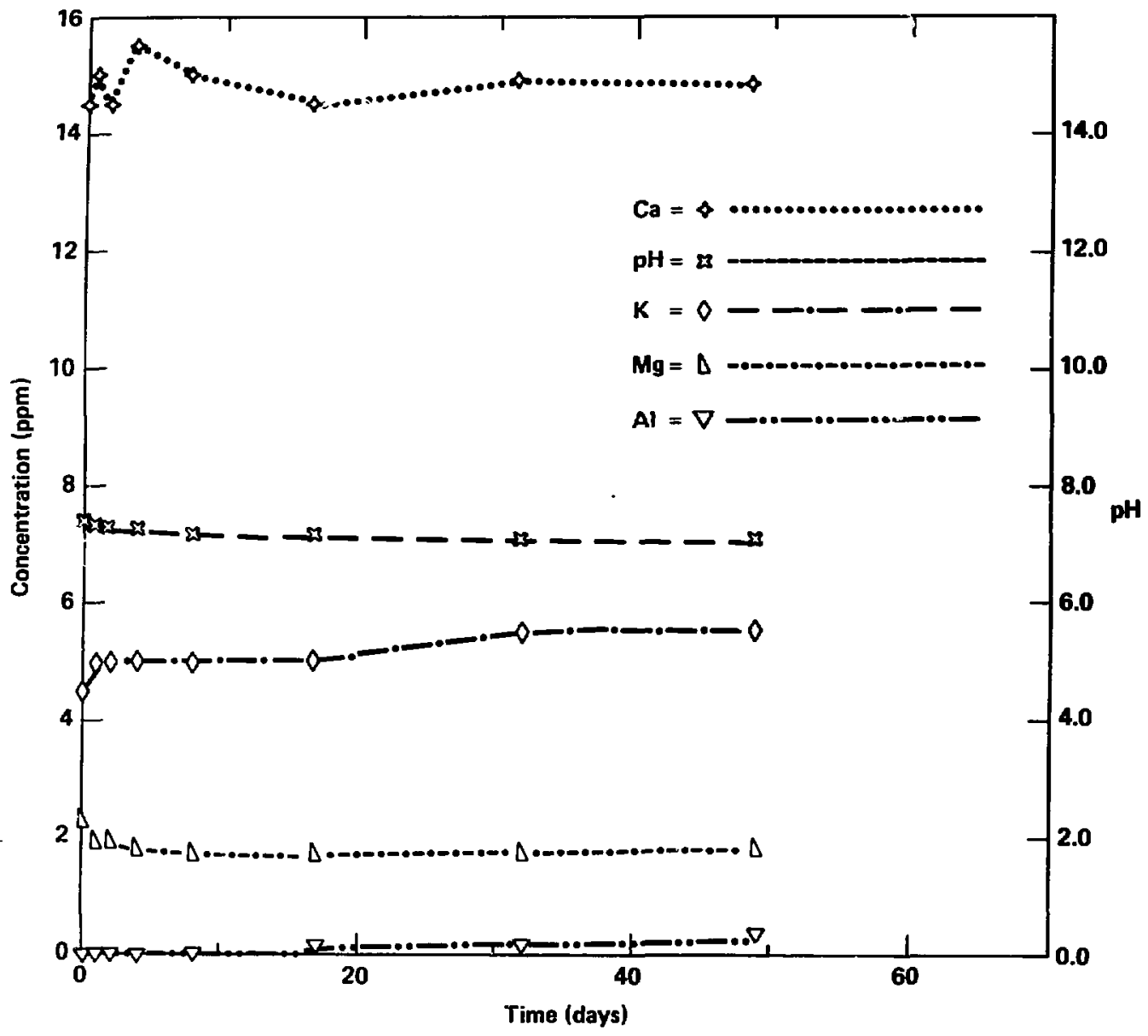

Figure 7. Aluminum, potassium, calcium, magnesium, and pH analyses from J-13 water reacted with G-1 core wafers at $90^{\circ} \mathrm{C}$ as a function of time in days (Knauss, et al., 1985b) 


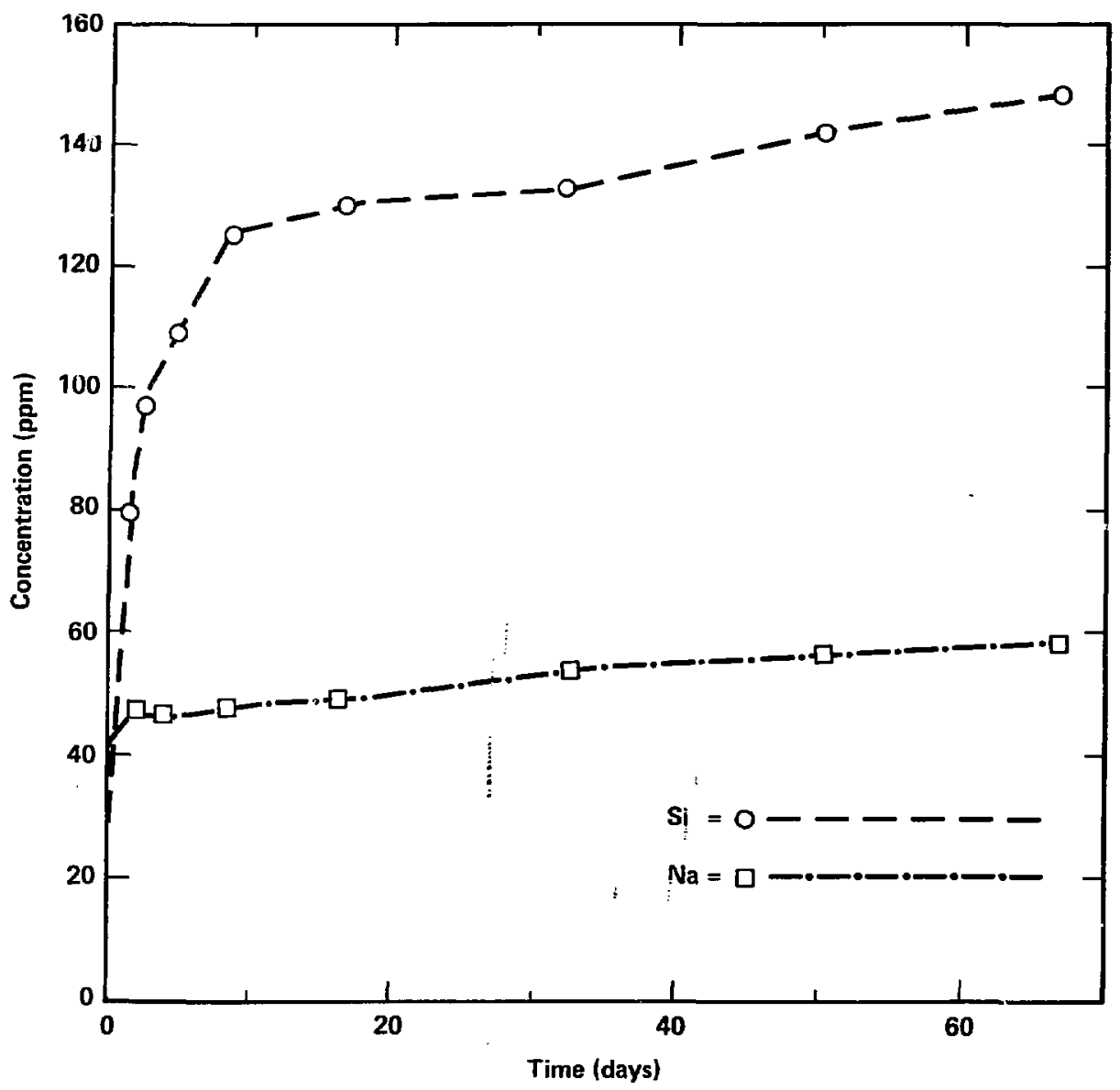

Figure 8. Silicon and sodium concentrations in J-13 water reacted with crushed G-1 material at $150^{\circ} \mathrm{C}$ as a function of time in days (Knauss et al., 1985a). 


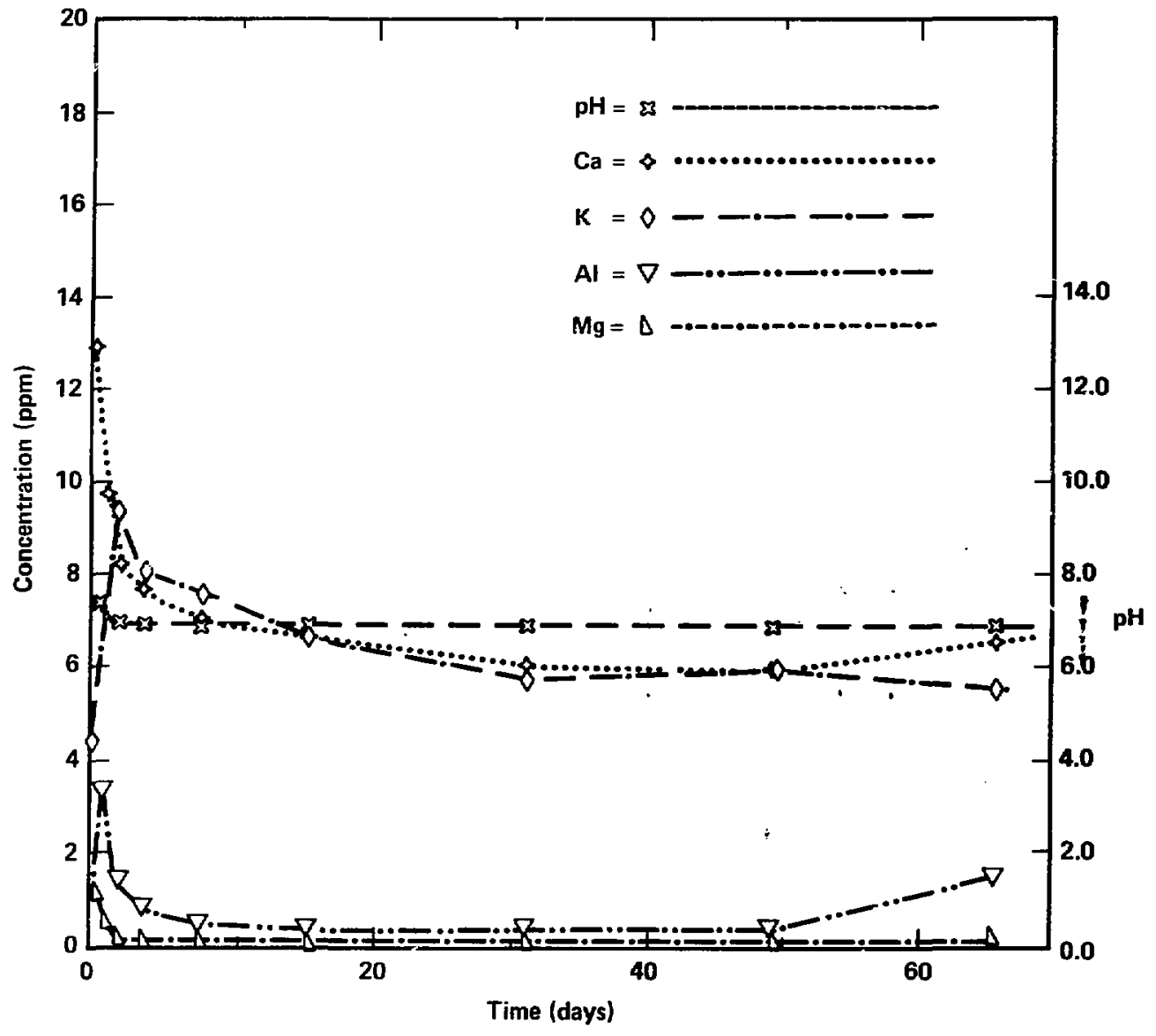

Figure 9. Aluminum, potassium, calcium, magnesium, and $\mathrm{pH}$ analyses from $\mathrm{J}-13$ water reacted with crushed G-1 material at $150^{\circ} \mathrm{C}$ as a function of time in days (Knauss et al., 1985:! 
run products (Knauss et al., 1986). Fluid composition trends obtained during the long-term experinents were generally similar to those obtained in the shorter term experiments, although differences in absolute abundances of cations were observed. Most of the differences reflect the effects of variable reaction kinetics on the rate of fluid compositicn evolution and on product phase precipitation. The results support the conclusion that the fluid composition remains benign, attaining low cation concentrations and near-neutral $\mathrm{pH}$.

Rock-water interaction tests conducted in Teflor capsuies contained in steel casings (Parr acid d.gestion bombs) have used crushed tuff and core wafer material prepared from outcrop samplec and reacted at $130^{\circ} \mathrm{C}$ and crushed material at $50^{\circ} \mathrm{C}$ (Knauss and Beiriger, 1984a; Oversby, 1984a). Tests have also been conducted using crushed outcrop material at $120^{\circ} \mathrm{C}$ (Oversby, $1984 \mathrm{~b})$. As expected, results from the latter tests W' $\mathrm{F}_{\mathrm{r}} \mathrm{e}$ intermediate between the 90 and $150^{\circ} \mathrm{C}$ results and will not be further discussed here.

The trends of solution chemistry with time were similar for the outcrop material and the USW G-1 crushed rock except for $\mathrm{pH}$, alkalinity, and final silicon concentration. The differences in alkalinity and $\mathrm{pH}$ are thought to be due to the uptake of carbon dioxide by the Teflon capsule resulting in lower amounts of dissolved carbonate species and higher pH (Knauss et al., 1983). The lower silicon concentrations found by Oversby (1984a) may be the result of lower effective surface area in the crushed rock (less than 60 mesh) in comparison to the 100 to 200 mesh material used by Krauss et al. (1985a). Results at $90^{\circ} \mathrm{C}$ showed parallel differences in $\mathrm{pH}$, alkalinity, and silicon. In addition, the calcium data from the outcrop samples were somewhat lower, with fini! concentrations of about $8 \mathrm{ppm}$ versus about $12 \mathrm{ppm}$ for the USW G-1 samples.

Oversby (1985) has examined the water chemistry resulting from reaction of Topopah Spring tuff with J-13 water as a function of lateral and vertical extent of the unit by using material taken from three vertical boreholes (USW G-1, USW GU-3, and USW G-4) and from the horizontal air-drilled hole at Fran Ridge. The solution chemistry after 70 days of reaction was very similar for all samples except that the silicon concentration was slightly lower for one of the Fran Ridge samples. The $\mathrm{pH}$ and alkalinity data show the expected differences from the gold-cell autoclave tests. Final silicon values ranged from 99 to $110 \mathrm{ppm}$ (excluding the low-silicon Fran Ridge sample), somewhat lower than the autoclave re- sults. Again the differences may be due to the different mesh size used, which affects the SA/V ratio of the test material. Data for aluminum, magnesium, and sodium are very similar, but potassium and calcium were lower in the Parr bomb tests as compared to the gold-cell autcclave tests. The lcwer calcium concentration may be due to the higher $\mathrm{pH}$, which increases carbonate relative to bicarbonate and may cause increased precipitation of calcite. The reason for the lower potassium ( 1 to $3 \mathrm{ppm}$ versus $6 \mathrm{ppm}$ ) is not understood.

The drill core samples were tested for the presence of readily soluble salts by treating with water at room temperature and also by heating with J-13 water overnight. This is the standard pretreatment procedure used on outcrup samples to remove evaporite salts. The resulting solutions showed no evidence of readily soluble material. This result is particularly significant for the samples from the air-drilled hole at Fran Ridge, since drilling fluid that might have removed soluble salts was not used in the portion of the hole from which the samples were obtained. This result strorgly suggests that the presence of soluble salts is a surface evaporation phenomenon and that such materials are unlikely to be present at the depth of the repository horizon (Oversby, 1985).

\section{Modeling of Rock-Water Interaction}

Results of the $150^{\circ} \mathrm{C}$ rock-water interaction tests were modeled using the EQ3/6 modeling code (Knauss et al., 1984b). The EQ3/6 code (Wolery, 1979, 1983) employs finite difference derivatives with a Taylor's series expansion to predict the equilibrium distribution of components between aqueous species as a reaction progress variable is incremented. Chemical affinities for all minerals that might occur in the system are then computed using a Newton-Raphson algorithm. If saturation of a phase is attained a mass action relationship is incorporated into the array of equations. The activities and molalities of all aqueous species and the number of moles per unit mass of water of each mineral produced or destroyed are then computed for each step in reaction progress.

The composition of J-13 water was used as input to EQ3NR to obtain a model aqueous solution for the reaction simulation. For the $150^{\circ} \mathrm{C}$ tests the dissolved aluminum concentration was constrained to satisfy the mineral solubility equilibria for kaolinite in order to reduce the number of supersatured phases listed by the model. The rock was represented in the EQ6 model by six 
minerals: sanidine, plagioclase, cristobalite, quartz, biotite, and montmorillonite. Specific surface area for each phase was calculated from the measured BET surface area of the rock wafer and the estimated abundance of each Fhase.

The precipitation of all silica phases less soluble than cristobalite was suppressed in order to allow the code to reproduce the silicon concentratoons. Clays initially present in the hydrothermal experiments were modeled by magnesiumbeidellite, a smectite clay that is a close compositional and structural analog to the montmorillonite identified in the experiments.

The EQ3/6 calculations realistically predicted that none of the initial reactants were exhausted and that a relatively minor amouni of the rock dissolved during the reaction interval. The final concentrations for all major cations in solution predicted by the model were close to the observed values. As silica in the form of quartz and cristobalite dissolves, its concentration increases to a steady state value, constrained by the input parameters to the steady state solubility of cristobalite. The cbserved sharp rise in aluminum can be attributed to rapid dissolution of a small amount of magnesium-beidellite included in the model rock assemblage. The initial drop in calcium is due to formation of minor amounts of calcite, while the continued decrease in calcium is due to precipitation of a calcium-bearing smectite clay. The formation of the calcium-bearing smectite clay in the model also lowers the aluminum concentration in the model reaction path. The initial rise in potassium in the actual reaction solutions cannot be accounted for by the model.

The kinetic rate laws included in the current version of EQ6 provide only for dissolution reactions. Precipitation. appears as an instantaneous process once saturation of a particular phase has been reached. Code development work is under way to include kinerically limited precipitation reactions in the EQ6 model.

The reaction path code used to model the experimental results uses equilibruim thermodynamics to establish the phase relationships. In the experimental system it is possible that metastable phases precipitate during reaction progress. Such behavior would be a consequence of the tendericy of natural and experimental systems to initially produce phases that have free energies that are between those of the reactants and those of the stable products of a discontinuous reaction (Ostwald, 1897). To account for the behavior of potassium it will probably be necessary to include a metastable potassium-bearing phase such as illite or smectite in order to model the observations. When appropriate thernodynamic data are available for these phases they will be incorforated in the code.

Delany (1985) has continued the reaction path modeling of the $150^{\circ} \mathrm{C}$ autoclave tests, extending the work to the results of investigations with crushed tuff. Estimates of dissolution kinetic parameters were improved from the earlier work (Knauss et al., 1984a) by using a combination of published rate constant data and additional kinetic constraints. Reported dissolution rate constants that are consistent with transition state theory and that extend to temperatures as high as $150^{\circ} \mathrm{C}$ are available for potassium-feldspar (Helgeson et al., 1984) and the silica phases (Rimstidt and Barnes, 1980). Dissolution rate constanis for pure albite are available to $70^{\circ} \mathrm{C}$ (Knauss and Wolery, 1985) and to $25^{\circ} \mathrm{C}$ for phlogopite (Lin and Clemency, 1981j. The dependence of the rate constants on temperature was estimated from transition state theory (Delany, 1985). The results of these most recert modeling efforts are compared in Fig. 10 with the observed solution compositions. There are still some discrepancies between the EQ6 reaction path model predictions and the experimental values, but in general the results are very promising.

The model was also extended to a system open to the atmosphere so that carbon dioxide and oxygen were available as reactants in essentially infinite supply. The model calculation was done at $150^{\circ} \mathrm{C}$ using the core wafer model parameters and a reaction interval of 100 years. EQ6 predicted that the solution composition would reach steady state at $150^{\circ} \mathrm{C}$ after 180 days. If adjustment is made to take account of the differences in rock surface-area-to-water volume ratios that are expected in the repository as compared to the experiments, the dissolution that occurs in one year of an experiment would be approximately comparable to the amount of dissolution occurring in about 1000 years in the repository (Delany, 1985). However, the approach to steady state concentrations should be faster in the repository because of the higher SA/V ratio.

The water chemistry measured in short-term tests and predicted through the use of reaction path modeling differed from the initial J-13 composition by having higher siiicnn, aluminum, and sodium concentrations, and lower calcium, magnesium, potassium, and dissolved inorganic carbon species. The $\mathrm{pH}$ remainıd near neutral, and no significant source of anions has been identified in the rock. The seconda: $y$ mineral assemblage prodaced by reaction at semperatures up to $250^{\circ} \mathrm{C}$ 

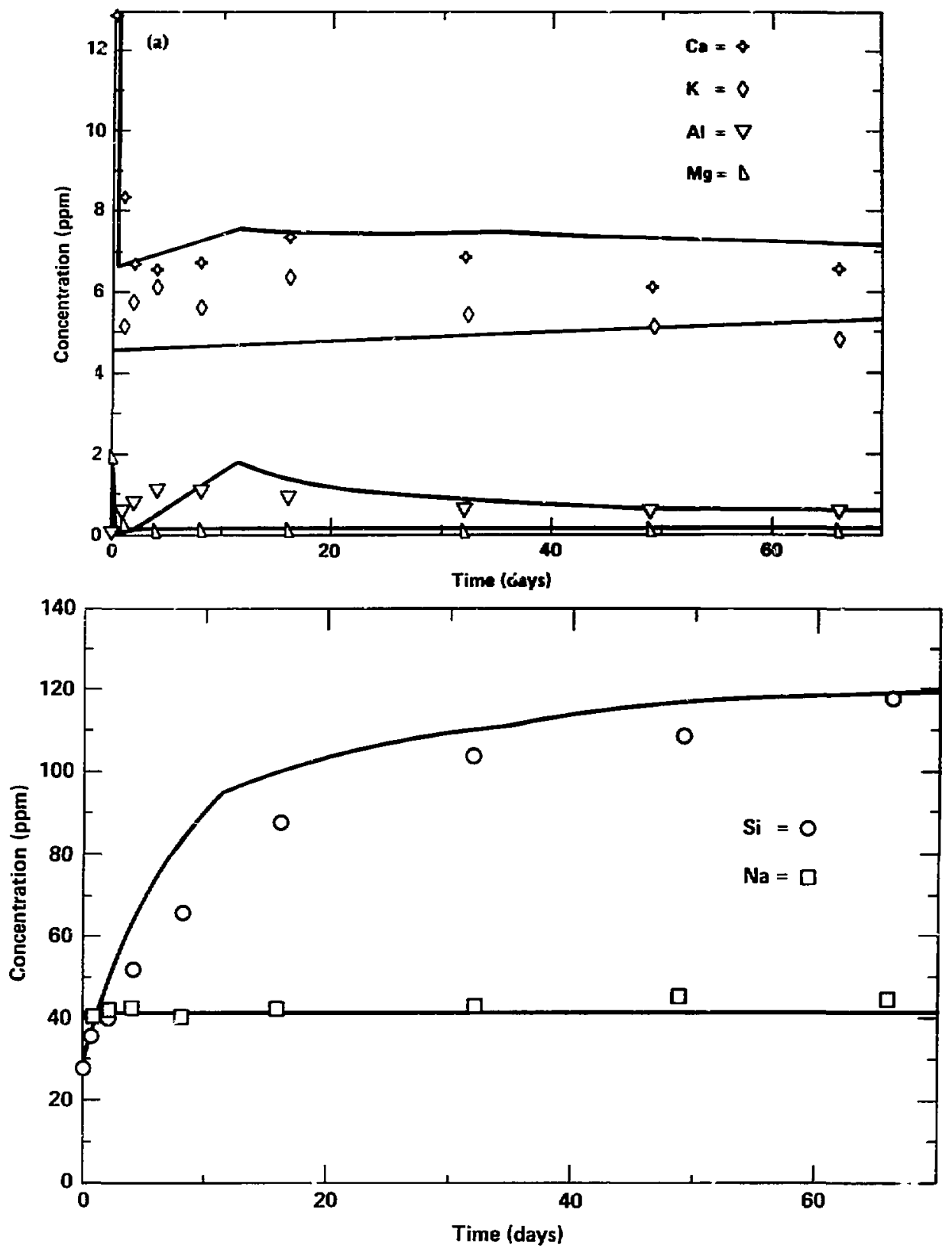

Figure 10. Comparison of fluid composition as given by EQ3/6 calculations (solid lines) and actual neasured values (symbols) for J-13 water reacted with Topopah Spring tuff at $150^{\circ} \mathrm{C}$. Figure $10(2)$ shows calcium, potassium, aluminum, and magnesium; Figure 10(b) shows silicon and sodium (Delany, 1985). 
consisted of clays, zeolites, and small amounts of other minerals. The dominant secondary minerals have high surface areas, high cation exchange capacity, and positive sorption capabilities. As such. alteration of the rock by hydrothermal reaction should contribute to the ability of the site to retand migration of radionuclides.

\section{Conclusions}

Current results suggest that the chemistry of aqueous liquid interacting with waste packages will not bo significantly modified by radiolytic processes. This conclusion is a consequence of the very low flux of ionizing radiation at the time when liquid water can exist in contact with the waste package. Prior to this time, near-field temperatures will excecd the boiling point of water and will cause the formition of a dehydrated envelope of rock surrounding the waste package.

Experimenta! studies suggest that there will be no observable change in the permeability of unfractured rocik within those portions of the waste package environment where dehydration may occur. In an experimental setting a decrease in Fermeability was observed for fractured samples that experienced dehydration-rehydration cycles. Deposition of solute materials on the fracture surface with a corresponding decrease in fracture aperture size appears to be responsible for the change in permeability. After several dehydrationrehydration cycles the permeability of the fractured sample was indistinguishable from that of unfractured rock.

The results of hydrothermal experiments in which J-13 water was reacted with tuff at elevated temperatures demonstrate that the composition of the water remains benign. The most significant compositional changes reflected dissolution of silicon from the tuff and loss of calcium, magnesium, and carbonate from the water. The $\mathrm{pH}$ of the fluid remained near neutral and the concentrations of the other anionic species were unchanged from unreacted J-13 water.

The chemical changes were accompanied by the development of reactant phases that included zeolites and clays. Because of their sorptive properties the growth of these phases during hydrothermal reactions would enhance retardation of radionuclide migration in the event waste packages were breached and waste material removed.

Table 4 summarizes the conditions anticipated to be present - ine repository horizon during pre- and post-emplacement periods.

Modeling of the hydrothermal experiments is in progress. Current results reproduce most of the attribules of the experimental system. However, further database development will be necessary before the EQ3/6 code can be used to predict with confidence the behavior of the tuff-water system.

\section{Future Activities}

Remaining uncertainties regarding the characteristics of the post-emplacement waste package environment will be addressed in work that is currently planned or now under way. Major future activities are described below.

\section{Radiation Field Effects}

The effects of different ionization fluxes on the tuff-water system will be quantified. Mixed systems including container material will be included in these studies, which will address uncertainties in the dbsolute abundances and relative proportions of radiolysis products in a system representative of the waste package environment.

\section{Thermal Effects on Water Flow in the Vicinity of Waste Packages}

Two-phase flow studies have been initiated. These studies will include variable proportions of gas and water at variable pressures. Impedance camera tomography will continue, emphasizing flow in thermal gradients in fractured and unfractured material as well as flow characteristics in unsaturated systems. These studies will characterize the mechanism responsible for changes in permeability during dehydration-rehydration cycles and will provide quantitative information necessary for fluid-flow modeling. 
Table 4. Anticipated conditions for waste package environment. See text for qualifications.

\begin{tabular}{|c|c|c|}
\hline Characteristics & Value & Source \\
\hline Fracture density & $8-40 / m^{3}$ & Scoit et al, 1983 \\
\hline Porosity & $14 \% \pm 5.5$ & Montazar and Wilson, 1994 \\
\hline Saturation & $65 \%=19$ & Montazar and Wilson, 194 \\
\hline Water flux (downward) & $<0.5 \mathrm{~mm} / \mathrm{y}$ & Montazar et al. 1985 \\
\hline Bulk rock composition & See Table 1 & Schuraytz, 1905 \\
\hline $\begin{array}{l}\text { Vadose water calion } \\
\text { composition }\end{array}$ & See Table 2 & Ogard and Kerrisk, I984 \\
\hline $\begin{array}{l}\text { Vadose water anion } \\
\text { composition }\end{array}$ & See Table 2 & Ogard and Kerrisk, $19 \%$ \\
\hline Vadose water pH & 6.9 to 7.6 & $\begin{array}{l}\text { Oversby 1984; } \\
\text { Knauss et al. 19.5b }\end{array}$ \\
\hline Maximum WPE temperature & $230^{\circ} \mathrm{C}$ & O'Neal et al. 19\%4 \\
\hline $\begin{array}{l}\text { Duration of dehydration } \\
\text { period }\end{array}$ & $>300$ years & O'Neal et al. 1984 \\
\hline $\begin{array}{l}\text { Maximum cation } \\
\text { concentrations in } \\
\text { solution during } \\
\text { high temperature } \\
\text { rock-water interaction }\end{array}$ & $\begin{array}{l}\mathrm{Si}<160 \mathrm{ppm} \\
\mathrm{Na}<65 \mathrm{ppm} \\
\mathrm{K}, \mathrm{Ca}<15 \mathrm{ppm} \\
\mathrm{Mg}, \mathrm{Al}<5 \mathrm{ppm}\end{array}$ & Knauss et al, 1985b \\
\hline $\begin{array}{l}\text { Maximum anion } \\
\text { concentrations in } \\
\text { soiution during } \\
\text { high temperature } \\
\text { rock-water interaction }\end{array}$ & $\begin{array}{l}\mathrm{HCO}_{3}^{-}<140 \text { ppm, } \\
\mathrm{Cl}<10 \mathrm{ppm} \\
\mathrm{NO}_{3}^{-}<15 \mathrm{ppm} \\
\mathrm{SO}_{\mathbf{i}}<25 \mathrm{Ppm} \\
\mathrm{F}<5 \mathrm{ppm}\end{array}$ & Knause et al. 19a5b \\
\hline
\end{tabular}

\section{Rock-Water Interaction}

Tests will give additional details of the products of hydrothermal interaction in systems typical of the waste package environment. Successful modeling of these interactions over long time periods requires further tests to provide additional data on phase composition and dissolution properties. Further modeling of rock-water interaction will incorporate the new thermodynamic data. 


\section{Bibliography}

Aagaard, P. and H. C. Helgeson (1982), "Thermodynamic and Kinetic Constraints on Reaction Rates Among Minerals and Aqueous Solutions. 1. Theoretical Considerations," Amer. Jour. Sci. 282, 237.

Baxter, R. G. (1983), Description of Defense Waste Processing Facility Reference Waste Form and Canister. E. 1. Dupont de Nemours \& Co., Savannah River Plant, Aiken, SC, DP-1606.

Beittie, I. R. (1967), "Nitrogen Dioxide and Dinitrogen Tetraoxide." in Mellow, Comprehensive Treatise on Inorganic and Theoretical Chemistry, v. VIII, Suppl. II (U. Wiley and Sons, New York, NY). p. 246.

Bish, D. L., F. A. Caporuscio, J. F. Copp, B. M. Crowe, J. D. Purson, J. R. Smyth, and R. G. Warren (1981), Preliminary Stratigraphic and Petrologic Characterization from Core Samples USW G-1, Yucca Mountain, Nevada, Los Alamos National Laboratory, Los Alamos, NM, LA-8840-MS.

Bish, D. L., D. T. Vaniman, F. M. Byers, Jr. and D. E. Broxton (1982), Summary of the Mineralogy-Petrology of Tuff of Yucca Mountain and the Secondary Phase Thermal Stability in Tuffs, Los Alamos National Laboratory, Los Alamos, NM, LA-9321-MS.

Braithwaite, J. W. (September 27, 1985), personal communication to U. S. Clanton, Science Applications International Corp.

Carlos, B. (1985), Minerals in Fractures of the Unsaturated Zone from Drill Core USW-G4, Yucca Mountain, Nye County, Nevada, Los Alamos National Laboratory, Los Alamos, NM, LA-10415-MS.

Daily, W., W. Lin, and T. Buscheck (1986), Hydrology of Topopah Spring Tuff: Laboratory Measurentents, Lawrence Livermore National Laboratory, Livermore, CA, in press.

Delany, J. M. (1985), Reaction of Topopah Spring Tuff with I-13 Water: A Geochenical Modeling Approach Using the EQ3/6 Reaction Path Code, Lawrence Livermore National Laboratory, Livermore, CA, UCRL-53631.

DePoorter, G. L. (January 17, 1986), personal communication to M. O. Valentine, Department of Energy. Drever, J. I. (1982), The Geochemistry of Natural Groundwaters (Prentice-Hall, Englewood Cliffs, NJ), p. 128. Durham, W. B., J. M. Beiriger, M. Axelrod, and S. Tretteners (1985), The Effect of Gamma Irradiation on the Strength and Elasticity of Climax Stock and Westerly Gratites, Lawrence Livermore National Laboratory, Livermore, CA, UCRL-92526.

Forsythe, W. R. and W. F. Giaque (1942), Jour. Amer. Chem. Soc. 64, 48.

Grasse, D., W. Kocar, J. Peirl and S. C. Moss (1982), "Diffuse $X$-ray Scattering from Neutron Irradiated Crystalline Quartz," Rad. Effects 66, 61.

Helgeson, H. C., J. M. Delany, H. W. Nesbitt, and D. K. Bird (1978), "Summary and Critique of the Thermodynamic P:operties of Rock-Forming Mineral," Amer. J. Sci. 278-A.

Helgeson, H. C. and W. M. Murphy (1983), "Calculation of Mass Transfer Among Minerals and Aqueous Solutions as a Function of Time and Surface Area in Geochemical Processes. I. Computational Approach," Math. Geol. 15, 109.

Helgeson, H. C., W. M. Murphy, and P. Aagaard (1984), "Thermodynamic and Kinetic Constraints on Reaction Rates Among Minerals and Aqueous Solutions. II. Rate Constants, Effective Surface Area, and the Hydrolysis of Feldspars," Geochim. Cosmochim. Acta 48, 2405.

Henne, M. S. (1982), The Dissolution of Rainier Mesa Volcanic Tuff, and lts Application to the Analysis of the Groundwater Enviromment, M.S. thesis, University of Nevada, Reno, NV.

Jones, A. R. (1959), "Radiation-Induced Reactions in the $\mathrm{N}_{2}-\mathrm{O}_{2}-\mathrm{H}_{2} \mathrm{O}$ System," Rad. Res. $10,655$.

Knauss, K. G. (1984), Petrologic and Geochemical Characterization of the Topopah Spring Member of the Paintbrush Tuff: Outcrop Samples Used in Waste Package Experiment, Lawrence Livermore National Laboratory, Livermore, CA, UCRL-53558.

Knauss, K. G., V. M. Oversby, and T. J. Wolery (1983), Post-Emplacement Environment of Waste Packages, Lawrence Livermore National Laboratory, Livermore, CA, UCRL-39475.

Knauss, K. G. and W. B. Beiriger (1984a), Report on Static Hydrothermal Alteration Studies of Topopah Spring Tuff Wafers in J-13 Water at $150^{\circ} \mathrm{C}$, Lawrence Livermore National Laboratory, Livermore, CA, UCRL53576 .

Knauss, K. G. and W. B. Beiriger (1984b), "Dachiardite Formation by Hydrothermal Alteration of a Devitrified High Silicn Rhyolite," Geol. Soc. Amer. Prog. Abstr. 16, 561.

Knauss, K. G., J. M. Delany, W. B. Beiriger, and D. W. Peifer (1984a), Hydrothermal Interaction of Topopah Spring Tuff with J-13 Water as a Function of Temperature, Lawrence Livermore National Laboratory, Livermore, CA, UCRL-90853. 
Knauss, K. G., V. M. Oversby, and T. J. Wolery (1984b), "Post-Emplacement Environment of Waste Packages," Material Res. Soc. Symp. 26, 301.

Knauss, K. G., W. B. Beiriger, and D. W. Peifer (1985a), Hydrothernal Interaction of C.ushed Topopah Spring Tuff and $\left[-13\right.$ Water at 90, 150, and $250^{\circ} \mathrm{C}$ Using Dirkson-Type, Gold-Bag Rocking Autoclaves, Lawrence Livermore National Laboratory, Livermore, CA, UCRL-53630.

Knauss, K. G., W. B. Beiriger, D. W. Peifer, and A. Piwinskii (1985b), Reaction of Solid Wafers of Topopah Spring Tuff with J-13 Water at 90, 150, and $250^{\circ} \mathrm{C}$ in Dickson-Type. Gold-Bag Rocking Autoclaves: 1. Short-Tern Experintents, Lawrence Livermore National Laboratory, Livermore, CA, UCRL-53645.

Knauss, K. G. and T. J. Wolery (1985), "Dependence of Albite Dissolution Kinetics on pH and Time at $25^{\circ} \mathrm{C}$ and $70^{\circ} \mathrm{C}, "$ Geochint. Cosmochim. Acta, in press.

Knauss, K. G., W. Beiriger, and D. Peifer (1986), Hydrothermal Interaction of Solid Wafers of Topopah Spring Tuff with J-13 Water at $90^{\circ} \mathrm{C}$ and $150^{\circ} \mathrm{C}$ Using Dickson-Type, Gold-Bag Rocking Autoclaves: 2. LongTerms Experiments, Lawrence Livermore National Laboratory, Livermore, CA, UCRL-53646.

Lagache, M. (1965), “Contribution a l'Etude de l'Alteration des Feldspathe dans l'Eau, Entre 100 et $200^{\circ} \mathrm{C}$, Sous Divirses Pressions de $\mathrm{CO}_{2}$, et Application a la Synthesis des Minereaux Argileaux," Soc. Frinc. Mineral. Cristal. Bull. 88, 223.

Levy, S. (1984), Petrology of Samples from Drill Holes USW G-3, H-4, and F-5, Yucca Mountain, Nevada, Los Alamos National Laboratory, Los Alamos, NM, LA-9706-MS.

Lin F. C. and C. V. Clemency (1981), "Dissolution Kinetics of Phlogopite. I. Closed System." Clays and Clay Minerals 29, 101.

Lin, W. and W. Daily (1984), Transport Properties of Tepopah Spring Tuff, Lawrence Livermore National Laboratory, Livermore, CA, UCRL-53602.

Lipman, P. W., R. L. Christensen, and J. T. O'Connor (1966), A Compositionally Zoned-Ash Flow Sheet in Southern Nevada, U.S. Geological Survey, Denver, CO, 524-F.

Montan, D., Lawrence Livermore National Laboratory, Livermore, CA, private communication (May 9, 1986).

Montazar, P. and W. E. Wilson (1984), Conceptual Hydrologic Model of Flow in the Unsaturated Zone, Yucca Mountain, Nevada, U.S. Geological Survey, Denver, CO, Water Resources Inv. Rep. 84-4345.

Montazar, P., E. P. Weeks, F. Thomas, S. P. Yarp, and P. B. Hofrichter (1985), "Monitoring the Water Zone in Fractured Tuff, Yucca Mountain, Nevada," National Water Well Association Symposium, Denver, CO, November 19-21.

Morrow, C. A., D. E. Moore, and J. D. Bysrlee (1981), "Permeability of Granite in a Temperature Gradient," J. Geophys. Res. 86, 3002.

Morrow, C. A., D. E. Moore and J. D. Byerlee (1985), "Permeability Changes in Crystalline Rocks Due to Temperature: Effects of Mineral Assemblage," Material Res. Soc. Symp. 44, 467.

Ogard, A. E. and J. F. Kerrisk (1984), Groundwater Chemistry Along Flow Paths Between a Proposed Repository Site and the Accessible Environment, Los Alamos National Laboratory, Los Alamos, NM, LA10188-MS.

O'Neal, W. C., D. W. Gregg, J. N. Hockman, E. W. Russell, and W. Stein (1984), Preclosure Analysis of Conceptual Waste Package Designs for a Nuclear Waste Repository in Tuff, Lawrence Livermore National Laboratory, Livermore, CA, UCRL-53595.

Ortiz, T. S., R. L. Williams, F. B. Nimick, B. C. Whittet, and D. L. South (1985), A Three-Dimensional Model of Reference Thermal/Mechanical and Hydrological Stratigraphy at Yucca Mountain, Southern Nevada, Sandia National Laboratory, Albuquerque, NM, SAND 84-1076.

Ostwald, W. (1897), Lehrbuch Der Ailgemeine Chemie (W. Engelmann, Leipzig).

Oversby, V. M. (1984a), Reference Waste Forms and Packing Material for the Nevada Nuclear Waste Storage Investigations Prnject, Lawrence Livermore National Laboratory, Livermore, CA, UCRL-53531.

Oversby, V. M. (1984b), Reaction of the Topopah Spring Tuff with J-13 Well Water at $90^{\circ} \mathrm{C}$ and $150^{\circ} \mathrm{C}$, Lawrence Livermore National Laboratory, Livermore, CA, UCRL-53552.

Oversby, V. M. (1984c), Reaction of Topopah Spring Tuff with J-13 Well Water at $120^{\circ} \mathrm{C}$, Lawrence Livermore National Laboratory, Livermore, CA, UCRL-53574.

Oversby, V. M. (1985), The Reaction of Topopah Spring Tuff with $\left[-13\right.$ Water at $150^{\circ} \mathrm{C}-$ Samples from Drill Cores USW G-1, USW GU-3, USW G-4, and UE-25h\#1, Lawrence Livermore National Laboratory, Livermore, CA, UCRL-53629. 
Oversby, V. M. and K. G. Knauss (1983), Reaction of Bullfrog Tuff with J-13 Well Water at $90{ }^{\circ} \mathrm{C}$ and $150^{\circ} \mathrm{C}$, Lawrence Livermore National Laboratory, Livermore, CA, UCRL-53442.

Rimstidt, J. D. and H. L. Barnes (1980), "The Kinetics of Silica-Water Reactions," Geochim. Cosmochim. Acte 44, 1683.

Schuraytz, B. (1985), Geuchemical Gradients in the Topopah Spring Member of the Paintbrush Tuff: Eoidence for Eruption Across a Magmatic Interface, Lawrence Livermore National Laboratory, Livermore, CA, UCRL-53698.

Scott, R. B., R. W. Spengler, S. Diehl, A. R. Lappin, and M. P. Chornack (1983), "Ceologic Character of Tuffs in the Unsaturated Zone at Yucca Mountain, Southern Nevada," in J. W. Mercer, P. S. C. Rao and I. W. Marim, Eds., Role of the Unsaturated Zone in Radioactive and Hazardous Waste Disposal (Ann Arbor Science, Ann Arbor, MI), p. 289.

St. John, C. M. (1985), Thermal Analysis of Spent Fuel Disposal in Vertical Emplacement Boreholes in a Welded Tuff Repository, Sandia National Laboratory, Albuquerque, NM, SAND 84-7207.

Travis, B. J., S. W. Hodson, H. E. Nuttal, T. L. Cook, and R. S. Rundberg (1984), Preliminary Estimates of Water Flow and Radionuclide Transport in Yucca Mountain, Los Alamos National Laboratory, Los Alamos, NM, LA-UR 84-40 (Rev.).

Vaniman, D. D. Bish, D. Broxton, F. Byers, G. Heiken, B. Carlos, E. Semarge, F. Caporuscio, and R. Gooley (1984), Variations in Authigenic Mineralogy and Sorptive Zeolite Abundance at Yucca Mountain, Nevada, Based on Studies of Drill Cores USW GU-3 and G-3, Los Alamos National Laboratory, Los Alamos, NM, LA-9707-MS.

Van Konynenburg, R. A. (1984), Radiation Doses in Granite Around Emplacentent Holes in the Spent Fuel Test-Climax (Final Report), Lawrence Livermore National Laboratory, Livermore, CA, UCRL-53580.

Van Konynenburg, R. A. (1986), Radiation Chemical Effects in Experiments to Study the Reaction of Glass in a Gamma-lrradiated Air, Groundwater, and Tuff Environment, Lawrence Livermore National Laboratory, Livermore, CA, UCRL-53719.

Wang, J. S. Y. and T. N. Narassimhan (1985), Hydrologic Mechanisms Gooeming Fluid Flow in Partially Fractured, Saturated, Porous Tufi at Yucca Mountain, Sandia National Laboratory, Albuquerque, NM, SAND 84-7202.

Warren, R. G., F. M. Byers, and F. A. Caporuscio (1984), Petrography and Mineral Chemistry of Units of the Topopah Spring, Calico Hills and Crater Flat Tuffs, and Older Volcanic Units, with Emphasis on Samples from Drill Hole USW G-1, Yucca Mountain, Nevada Test Site, Los Alamos National Laboratory, Los Alamos, NM, LA-10003-MS.

White, A. F., H. C. Claasen, and L. V. Benson (1980), The Effect of Dissolution of Volcanic Glass on the Water Chemistry in a Tuffaceous Aquifer, Rainier Mesa, Nevu. a, U.S. Geological Survey, Denver, CO, 1535-Q.

Wilcox, T. P. and R. A. Van Konynenburg (1981), Radiation Dose Calculations for Geologic Media Around Spent Fuel Emplacement Holes in the Climax Granite, Nevada Test Site, Lawrence Livermore National Laboratory, Livermore, CA, UCRL-53159.

Wolery, T. J. (1979), Calculation of Cnemical Equilibrium Between Aqueous Solution and Minerals: The EQ3/6 Software Package, Lawrence Livermore National Laboratory, Livermore, CA, UCRL-52658.

Wolery, T. J. (1983), EQ3NR-A Computer Program for Geochemical Aqueous Speciation-Solubility Calculations: Users Guide and Documentation, Lawrence Livermore National Laboratory, Livermore, CA, UCRL-53414.

Wolfsberg, K. and D. T. Vaniman (Eds.) (1984), Research and Development Related to the Nevada Nuclear Waste Storage Investigations, Los Alamos National Laboratories, Los Alamos, NM, LA-10032-PR. 